\title{
EL HISPANISMO AUTORITARIO ESPAÑOL Y \\ EL MOVIMENTO NACIONALISTA ARGENTINO: BALANCE DE MEDIO SIGLO DE RELACIONES POLÍTICAS E INTELECTUALES (1898-1946)*
}

\author{
EduARdo González CAlleja \\ Universidad Carlos III de Madrid
}

RESUMEN: En este estudio comparado de las mutuas influencias establecidas entre el nacionalismo autoritario español y el argentino se demuestra que los hispanófilos de otro lado del Atlántico se inspiraron en fuentes doctrinales muy diversas, desde el nacionalcatolicismo menendezpelayista al liberalismo institucionista, el casticismo de Unamuno el europeísmo de Ortega, el clasicismo novecentista de D'Ors o la Hispanidad de Maeztu. De mediados de los años treinta a mediados de los años cuarenta, las diversas tendencias nacionalistas integradas en el régimen franquista no lograron imponer la desaparición de los nacionalismos alternativos liberal-democráticos y periféricos en el debate político en Argentina. Aunque los nacionalismos autoritarios españoles impregnaron en muy diversa medida a los intelectuales nacionalistas argentinos de cuño católico, su repercusión resultó muy relativa, ya que actuaron como modelos circunstanciales de algunos regímenes políticos. Pero su deriva imperialista explícita y su vinculación con los regímenes fascistas a inicios de los cuarenta limitaron de forma irreversible su capacidad de influencia en Argentina.

PAlabras Clave: España. Argentina. Nacionalismo. Catolicismo. Fascismo. Siglo XX.

ABSTRACT: This comparative essay on mutual influences between Spanish and Argentinian autboritarian nationalisms shows that overseas hispanophiles were inspired on different peninsular doctrinal sources, like the Menéndez Pelayo's national-Catholicism, the liberalism of the Institución Libre de Enseñanza, the Miguel de Unamuno's casticism,

* El presente trabajo es el texto, ampliado y puesto al día, de una conferencia pronunciada en el Centro Cultural de España en Buenos Aires el 8 de septiembre de 2003. Ha sido realizado con cargo al Proyecto de Insvestigación HUM2004-00406/HIST. 
the Ortega's europeanism, the D'Ors' classicism or the Maeztu's Hispanidad. From balf-thirties to half-forties, the different trends of Spanish nationalism integrated in the Francoist regime failed to impose the disappearance of alternative liberaldemocratic and peripheral nationalisms in the Argentinian political debate. Altbough authoritarian Spanish nationalism influenced the activity of Argentinian catholic intellectuals in different ways, their real effect was very relative, because they acted only as circumstantial models to some Argentinian political regimes. But their imperialist development and their relations with the fascist regimes at the beginning of the forties restricted their possibilities of influence in Argentina in a totally irreversible way.

KEY WORDS: Argentina. Nationalism. Catholicism. Fascism. $\mathbf{X X}^{\text {th }}$ Century.

La evolución política e ideológica del nacionalismo autoritario en España y Argentina en la primera mitad del siglo XX muestra algunas coincidencias cronológicas y ciertas similitudes de partida que inducen a situarlos como manifestaciones secuenciales de un fenómeno de alcance global: la aparición en diversos países occidentales de una derecha radical, antiliberal y antipositivista que dominó el debate político de fin de siglo y fue el antecedente intelectual necesario para el desarrollo del fascismo. Como en otras latitudes, y a imagen de los paradigmáticos nacionalismos contrarrevolucionarios francés o italiano, la derecha radical surgió a uno y otro lado del Atlántico a fines del XIX como un movimiento de reacción cultural impulsado por minorías elitistas que se lamentaban de su marginación de los grandes centros de decisión constituidos en torno a regímenes liberales clásicos. Un liberalismo que reputaban en crisis de representación por su incapacidad para reaccionar con energía a los retos básicos de la modernidad, como la aparición de la política de masas (con sus «riesgos» de deriva democrática o revolucionaria), la acomodación de instituciones tradicionales como la Iglesia y el Ejército a las nuevas corrientes secularizadoras y civilistas, la integración de los factores productivos de estas regiones periféricas en el sistema de intercambios capitalista, o la posición económica, política y cultural a adoptar ante los avances del imperialismo moderno.

$\mathrm{Al}$ menos en sus orígenes, el patriotismo oficial español no tuvo esa impronta reactiva y católica que tras la crisis de 1898 acabó por prevalecer sobre un nacionalismo laico y progresista trabajosamente construido y difundido a lo largo del siglo XIX ${ }^{1}$. Por el contrario, en Argentina el término «nacionalismo» parece designar con más rotundidad a un movimiento político-intelectual que

1 Álvarez Junco, José: Mater Dolorosa. La idea de España en el siglo XIX, Madrid, Taurus, 2001, p. 601. Un buen estudio sobre la evolución histórica e ideológica de un nacionalismo democrático alternativo al «españolismo» conservador dominante durante la Restauración, en la obra de Blas Guerrero, Andrés de: Tradición republicana y nacionalismo español, 1876-1930, Madrid, Tecnos, 1991. 
en sus varias tendencias (integrismo católico, filofascismo, nacionalismo oligárquico, militarismo, nueva derecha) ha acostumbrado a representar (aunque no en todas sus manifestaciones) diversas opciones extrema derecha, frente al liberalismo residual del conservadurismo y el democratismo de los grupos reformistas, especialmente el radicalismo dominante en la política republicana durante el primer tercio de siglo XX. Esta naturaleza fundamentalmente proteica del nacionalismo español finisecular posibilitó que los hispanófilos argentinos - que nunca formaron una neta mayoría en el seno de la extrema derecha autóctona- bebieran de fuentes doctrinales muy diversas, desde el nacionalcatolicismo menendezpelayista al liberalismo institucionista, del casticismo de Unamuno al europeísmo de Ortega, o del clasicismo novecentista de D'Ors a la Hispanidad de Maeztu.

En ambos países el nacionalismo fue adoptando, al hilo de la crisis doméstica y global de la primera mitad del siglo XX, una impronta netamente autoritaria. Nunca fueron, sin embargo, movimientos homogéneos, y difícilmente lograron superar con éxito el estadio de grupo de presión intelectual. Formaron el think tank de diversas formaciones de derecha radical y fascista, pero jamás alcanzaron el poder como partido (el caso de Falange es excepcional en sus peculiaridades), y se vieron relegados en las experiencias dictatoriales que ayudaron a alumbrar con su crítica global al régimen representativo.

\section{EL 98 ESPAÑOL Y LA PRIMERA GENERACIÓN NACIONALISTA ARGENTINA}

El positivismo, con sus principios anejos de progreso, materialismo y cosmopolitismo, alcanzó su cenit de influencia en la conformación de la nacionalidad argentina entre 1880 y 1910. Sin embargo, en las dos últimas décadas del siglo se percibieron los primeros atisbos de una reacción que tuvo su manifestación inicial en el conflicto librado en 1880 en torno a la educación laica estatal, impuesta bajo la inspiración de la campaña emprendida por la Tercera República francesa. El liberalismo introducido sistemáticamente en el país por el grupo rivadaviano, profundizado por la generación de 1837 (Sarmiento, Alberdi, Echeverría) y llevado plenamente a la práctica por la generación de 1880, fue contemplado por sus enemigos como la causa del caos que, a su juicio, ponía a la Argentina tradicional en trance de disolución. Fue precisamente de Francia, mentora ideológica en la configuración inicial del nacionalismo conservador de las jóvenes repúblicas latinoamericanas, de donde partieron los primeros ataques sistemáticos al liberalismo, gracias a la difusión de las doctrinas nacionalistas antirrevolucionarias formuladas por Maurice Barrès o Charles Maurras $^{2}$. La filosofía política de este último, basada en el principio analítico

2 Sobre esta influencia, vid. Devoto, Fernando J.: Nacionalismo, fascismo y tradicionalismo en la Argentina moderna. Una historia, Buenos Aires, siglo XXI, 2002, pp. 195-205 y ZulETA ÁlvareZ, 
del «empirismo organizador», parecía brindar una sólida base científica a la crítica de la democracia, pero su irrenunciable monarquismo y su catolicismo puramente táctico le alejaban del sentir de la mayor parte de las clases ilustradas latinoamericanas. De hecho, esta primera generación nacionalista de inicios de siglo no asumió con franqueza las premisas doctrinales del maurrasismo, aunque compartió su crítica al liberalismo político y cultural y la agresividad con que afirmaba la singularidad de cada nación ${ }^{3}$.

Las ideas tradicionalistas desarrolladas en España a lo largo del siglo XIX bajo la inspiración de la contrarrevolución francesa (Balmes, Donoso Cortés, Aparisi y Guijarro) tuvieron también una acogida relativa en Argentina hasta fines de siglo ${ }^{4}$. El antiespañolismo de la primera generación de liberales de la república independiente, representada por Sarmiento, Mitre o Alberdi, fustigaba la inhabilidad hispana para el progreso material, pero valoraba sin embargo la lengua y la cultura heredadas de la metrópoli. La llegada masiva de la emigración popular española, el contacto cultural más intenso entre los intelectuales de ambos países a partir de 1860 y, sobre todo, la liquidación colonial que intensificó la severa crítica del «ser nacional» emprendida con anterioridad por el regeneracionismo ${ }^{5}$, posibilitaron una paulatina recuperación del prestigio cultural de España en América, permitiendo el desarrollo del hispanoamericanismo como alternativa cultural frente a las manifestaciones más agresivas del imperialismo estadounidense. El redescubrimiento esteticista de lo nacional y de lo popular («castizo») abordado por la «Generación del 98» fue debilitando el antihispanismo que había prevalecido entre las clases cultas latinoamericanas durante el siglo XIX, a impulso de la admiración por Francia e Inglaterra. Esa actitud más favorable se nutría además de la sintonía estética con el modernismo (con su evocación artística del pasado), de la crítica finisecular al racionalismo positivista y de la hostilidad política mostrada al nacionalismo universalista liberal, que se aspiraba a sustituir por el nacionalismo particularista,

Enrique: «Francia en las ideas políticas y en la cultura argentina», en Boletín de Estudios Políticos y Sociales (Mendoza), no 14, pp. 7-40.

3 Zuleta Álvarez, Enrique: España en América. Estudios sobre la historia de las ideas en Hispanoamérica, Buenos Aires, Confluencia, 2000, p. 312.

${ }^{4}$ Sobre la recepción del hispanismo tradicionalista entre la corriente «restauradora» latinoamericana, vid. RAMA, Carlos M.: Historia de las relaciones culturales entre España y América Latina, México, Fondo de Cultura Económica, 1982, pp. 112-114.

5 La difusión de obras como las de MALLADA, Lucas: Los males de la patria y la futura revolución, Madrid, Tip. de Manuel Ginés Hernández, 1890; GANIVET, Ángel: Idearium español, Granada, Tip. Lit. Carlos M. Vda. e Hijos de Sabatel, 1897; Macías PiCAVEA, Ricardo: El problema nacional, Madrid, Librería General de Victoriano Suárez, 1899 o CosTA, Joaquín: Oligarquía y caciquismo, Madrid, Hijos de Manuel Ginés Hernández,1902, permitieron una mayor sintonía con los intelectuales americanos enfrentados a sus propios problemas de identidad nacional (SEPÚLVEDA MUÑOZ, Isidro: Comunidad cultural e hispano-americanismo, 1885-1936, Madrid, UNED, 1994, p. 52). La reforma política argentina encontró en esta uno de sus modelos de inspiración (BOTANA, Natalio: El orden conservador, Buenos Aires, Sudamericana, 1979). 
telúrico y antimodernista de la nueva derecha radical. De esta actitud participaron figuras destacadas de la «Generación del Centenario», que constituyó la primera y heterogénea avanzada nacionalista que con el correr de los años pasaría a militar en las filas de la derecha autoritaria explícita ${ }^{6}$. Esta derecha explícitamente autoritaria estaba formada entre otros por Leopoldo Lugones, Ángel Guido, Benjamín Villafañe, Manuel Gálvez, Manuel Carlés, Marcelo G. Sánchez Sorondo, monseñor Gustavo J. Franceschi, Carlos Ibarguren, Gustavo Martínez Zuviría («Hugo Wast»), Benjamín Villafañe o el general José Félix Uriburu, la mayor parte de ellos nacidos entre 1870-90, formados en el clima de ideas de 1880, y que en los años veinte defendían los principios antiliberales y corporativos del fascismo italiano, aunque se orientaron de preferencia a los modelos políticos ibéricos de Oliveira Salazar o Primo de Rivera. Como los escritores del 98 español, estos nuevos nacionalistas eran en su mayor parte vástagos de grandes familias provincianas venidas a menos, que buscaban en lo hispano un factor histórico decisivo del carácter nacional argentino frente al peligro de desnaturalización del país y la amenaza de dependencia económica.

La intensificación de los intercambios culturales desde inicios de siglo favoreció la sintonía entre ambos grupos. Manuel Ugarte, Ricardo Rojas o Manuel Gálvez viajaron a España y recibieron en diverso grado esta impregnación de los valores hispánicos tradicionales, reaccionando contra el materialismo imperante en los círculos oficiales argentinos, a los que censuraban su despreocupación por la identidad y la personalidad nacionales ${ }^{7}$. Rojas viajó a España en 1907, y se interesó inmediatamente por el hispanismo, aunque su reivindicación de España quedó eclipsada por un proyecto nacionalista afrancesado en su propuesta de emplear la historia como principal instrumento nacionalizado. En La restauración nacionalista condenó el liberalismo de Sarmiento y Alberdi como extranjerizante, y en obras como La Argentinidad optó por una conciencia y un ideal típicamente argentinos, con los valores del «telurismo» y el «indianismo», dentro de una idea democrática universalista ${ }^{8}$. El caso del novelista Manuel Gálvez resulta paradigmático de esta conversión, donde la crítica de las condiciones reinantes en Argentina se abordaba sentimentalizando el legado histórico-cultural de España en un tono muy «noventayochista»: «Fascinado por España, el más profundo e inquietante pueblo que conozco, recorrí $[\ldots]$ sus más interesantes regiones; experimenté las más íntimas emociones de mi vida y recogí en las viejas ciudades de Castilla múltiples ense-

6 Una nómina de escritores de la «Generación de 1900», vagamente anarquizante pero transida de piedad católica, que en su mayor parte apoyó al bando franquista en la guerra civil española, en FALCOFF, Mark, "Argentina», en FALCOFf, Mark y PIKE, Frederick B. (eds.): The Spanish Civil War. Americam Hemispheric Perspectives, Lincoln-Londres, University of Nebraska Press, 1982, p. 330.

7 Vid. PAYÁ Carlos y CÁRDENAS, Eduardo: El primer nacionalismo argentino en Manuel Gálvez y Ricardo Rojas, Buenos Aires, Ed. Peña Lillo, 1978, pp. 69 ss.

8 ROJAS, Ricardo: La restauración nacionalista. Crítica de la educación argentina y bases para una reforma en el estudio de las humanidades modernas, Buenos Aires, Impta. de la Penitenciaría, 1909 y La Argentinidad. Ensayo histórico sobre nuestra conciencia nacional en la gesta de la emancipación, 1810-1816, Buenos Aires, La Facultad, 1916. 
ñanzas»`. Gálvez, que en 1901 impulsó con un pequeño grupo de estudiantes de la Universidad de Buenos Aires el periódico literario Idea en una línea antimaterialista, nacionalista y antipositivista, viajó a España en 1905 y 1910, y reconoció haber aprendido de la Generación del 98 a «enseñar incesantemente el amor por el país, por sus paisajes, por sus escritores, por sus grandes hombres» ${ }^{10}$.

Para Gálvez, España, «donde la vida se había detenido hacía tres siglos», continuaba encarnando los «valores espirituales» que deseaba trasladar a la Argentina. España era la matriz cultural de Argentina, pero el éxito de ésta como proyecto nacional no consisitia en un retorno a la tradición, sino en la capacidad de amalgamar los nuevos elementos del cosmopolitismo migratorio en torno a este núcleo cultural originario. Al igual que Ganivet, pensó que en el interior de la Argentina habitaba la verdad de la nación. Gálvez aseguraba que «a pesar de la inmigración y del ambiente americano hay algo muy profundo en nosotros que fuera de nosotros sólo en España lo encontramos y que sólo en España nos renace y nos resalta interiormente» ${ }^{11}$. La «obra de evangelización» de esa primera generación nacionalista consistiría en trasladar a Argentina esos valores hispanos revelados por la "Generación del 98», recuperando las tradiciones y los valores telúricos de la provincia como salvación de la nacionalidad $^{12}$. El objetivo era lograr el predominio de lo castizo, que en Argentina derivaba de la conjunción de elementos criollos y españoles, como factor básico de identificación nacional capaz de absorber y modificar por la fuerza del espíritu los elementos foráneos que se incorporasen al país ${ }^{13}$.

Esta admiración intelectual también se practicaba en sentido contrario. Desde Vicente Blasco Ibáñez a José Ortega y Gasset, los cada vez más numerosos intelectuales españoles que visitaron Argentina desde inicios de siglo daban muestra de su admiración sin límites por el avance material y cultural del país, especialmente tras los emblemáticos viajes de Rafael Altamira y Adolfo González Posada a fines de la década de los diez ${ }^{14}$. Muchas de estas figuras aprovecharon

9 GÁlvez, Manuel: El solar de la raza, Buenos Aires, Nosotros, 1913, p. 20.

${ }_{10} \mathrm{Ibid}$., pp. 15-16. En El espiritualismo español, Buenos Aires, Bayardo, 1921, Gálvez también reivindica la esencia hispana frente al cosmopolitismo liberal.

${ }^{11}$ GÁlvez, Manuel: El diario de Gabriel Quiroga. Opiniones sobre la vida argentina, Buenos Aires, Moen, 1910, pp. 65-66.

12 GÁLVEZ: El solar de la raza, p. 15

13 QuijadA, Mónica: Manuel Gálvez: 60 años de pensamiento nacionalista, Buenos Aires, Centro Editor de América Latina, 1985, p. 30. Sobre Gálvez, vid. también Devoto: Nacionalismo, fascismo y tradicionalismo en la Argentina moderna, pp. 42-53; Esther Hadasah Scott TURNER, Hispanism in the Life and in the Works of Manuel Gálvez, Ph.D., Washington University, 1958 y ZulETA Álvarez, Enrique: «España y la visión histórica de Manuel Gálvez», en Investigaciones y Ensayos (Buenos Aires), $\mathrm{n}^{\mathrm{o}} 45,1995$, pp. 185-205.

${ }_{14}$ Sobre estas misiones, vid. PIKE, Frederick B.: Hispanismo, 1898-1936. Spanish Conservatives and Liberals and Their Relations with Spanish America, Nôtre Dame-Londres, University of Nôtre Dame Press, 1971, pp. 152-157. Se podrían aportar numerosos testimonios de la idealización de la Argentina como representación del progreso y de los logros políticos y sobre todo económicos que podía alcanzar la raza hispánica, de poder superar los obstáculos institucionales y culturales 
las invitaciones cursadas por la influyente Institución Cultural Española, creada en 1912 por la colonia peninsular residente Buenos Aires. Por allí pasaron, entre otros, Ramón Menéndez Pidal, Julio Rey Pastor, Augusto Pi i Sunyer, Blas Cabrera, Ramiro de Maeztu, Claudio Sánchez Albornoz, José María Ots Capdequí, Sebastián Recasens o Jacinto Benavente. Otros autores, como Américo Castro, Eugenio D’Ors y otros miembros de movimiento novecentista, como Gregorio Marañón, Ramón Pérez de Ayala, José María Salaverría, Benjamín Jarnés, Antonio Marichalar, Fernando Vela, Ricardo Baeza, Melchor Fernández Almagro o Salvador de Madariaga, fueron calurosamente acogidos en revistas como Nosotros, Síntesis o Criterio. Sin embargo, como señala Pike, los excesos de la revolución mexicana, el auge del clericalismo en Colombia y Perú y la inestabilidad política en Argentina y Chile, así como el creciente predominio de los sentimientos indigenistas en una nueva generación de intelectuales, decepcionaron a numerosos americanistas españoles de raigambre liberal, que comprobaron cómo el liderazgo del movimiento pasaba a los conservadores, fortalecidos por el desarrollo en América de proyectos revisionistas y panhispanistas, que buscaban en la España eterna el modelo para guiarlos a la grandeza del pasado ${ }^{15}$.

\section{LA CRISIS DE LA POSGUERRA Y LA MODERNIZACIÓN DEL NACIONALISMO}

El desánimo de los hispanistas españoles fue en aumento tras el fin de la Primera Guerra Mundial. El abatimiento quedaba justificado por la apatía del Estado ante las grandes posibilidades de expansión cultural y económica abiertas durante la guerra, que no implicaron la puesta en marcha de proyectos para mejorar las comunicaciones o proporcionar las infraestructuras precisas para potenciar el acercamiento intelectual y comercial con América ${ }^{16}$. Con todo, fue la época dorada de la influencia del nacionalismo liberal español, de la mano de los sucesivos viajes (1916 y 1928) de José Ortega y Gasset, calificado por Francisco Romero de «jefe espiritual del pensamiento hispánico» ${ }^{17}$. Aunque la revis-

acumulados en la Península durante siglos. Sobre la fascinación por Argentina, y en concreto por Buenos Aires como urbs magna, "Atenas del Plata» o "Cartago del Sur», vid. BiAGINI, Hugo: Intelectuales y políticos españoles a comienzos de la inmigración masiva, Buenos Aires, Centro Editor de América Latina, 1995, pp. 55-65.

15 Pike: Hispanismo, pp. 164-165. Según Sepúlveda: Comunidad cultural e hispanoamericanismo, p. 68, para los panhispanistas conservadores, América no era un estímulo para la modernización, sino un «objeto de definición nacionalista española, un recuerdo de su grandeza pasada y un espejo de su propia identidad».

${ }_{16}$ A fines de 1922, Leopoldo Lugones pronunció un discurso proponiendo la fundación en Madrid de un Instituto de Cultura Hispánica, que organizara el intercambio de intelectuales de España y América.

17 RojAs, Ricardo: Retablo español, Buenos Aires, Losada, 1938, p. 341. Sobre los viajes de Ortega a la Argentina, vid. Molinuevo, José Luis (coord.): Ortega y la Argentina, México, Fondo de Cultura Económica, 1997. 
ta Sur, dirigida por Victoria Ocampo, fue su portavoz preferido en Argentina, tanto él como Eugenio D’Ors (que viajó en 1921) influyeron de forma apreciable en la «Nueva Generación» de intelectuales antipositivistas que surgió desde 1918 en el Colegio Novecentista en Buenos Aires. Y es que, en plena crisis de la democracia en Europa, los escritores nacionalistas no escatimaron elogios a las consideraciones elitistas y al «imperativo de selección» presentes en España invertebrada (Madrid, Calpe, 1921) y en La rebelión de las masas (Madrid, Impta. de Galo Sáez, 1929). Ortega viajó por tercera vez a la Argentina en 1938, pero rehuyó declararse por uno de los bandos en lucha, aunque el mundo intelectual porteño le situó en esa época muy cercano a las tesis del nacionalismo ${ }^{18}$.

No cabe duda de que la crisis política y moral de la primera posguerra mundial posibilitó la modernización del ideario nacionalista en Europa y América. De 1925 a 1930, el nacionalismo argentino pasó por una segunda etapa de desarrollo, estimulado por los conflictos en torno a la emigración, el acercamiento a la cuestión social con el auge del movimiento obrero y la crítica teórica a la democracia representada en el radicalismo gobernante. Ese nacionalismo radical de cuño hispanista estuvo muy vinculado al desarrollo del pensamiento autoritario en la propia España. En 1924, con la Dictadura recién instalada, Leopoldo Lugones (una de las más polémicas figuras intelectuales de la época, cuya evolución política e intelectual del nietzscheanismo clasicista al nacionalismo de estilo maurrasiano tanto se asemeja a la de Ramiro de Maeztu, aunque no ocultaba su desdén por la tradición hispánica y católica) señalaba en el discurso que dedicó en Lima el centenario de la batalla de Ayacucho que había llegado «la hora de la espada», y definía al Ejército como «religión de la nación» y «civilización de la fuerza», señalando el camino a seguir para una «regeneración nacional» de Argentina centrada en la adopción de valores militaristas ${ }^{19}$. El régimen autoritario establecido en España resultaba, sin duda, un modelo plausible para el nacionalismo argentino más conservador. Manuel Gálvez señaló que las modernas dictaduras contrarrevolucionarias de Europa eran un hecho «exclusivamente grecolatino», que permitía restablecer el orden jerárquico, imponer el respeto al poder, reponer a la Iglesia en su verdadero lugar y restablecer la moralidad y la política clásica, en que la razón no estaba dominada por el instinto ${ }^{20}$.

18 Vid. Etchecopar, Máximo: Ortega en la Argentina, Buenos Aires, Institución Ortega y Gasset, 1983.

19 Lugones, Leopoldo: «El discurso de Ayacucho», en La Patria fuerte, Buenos Aires, Círculo Militar (Biblioteca del Oficial), 1930, p. 19. Resulta interesante comparar esos términos con los expresados por MAEZTU, Ramiro de: «El Ejército nos ha salvado», en $A B C$ (Madrid), 26-X-1934 (también en MAezTU, Ramiro de: Frente a la República, Madrid, Rialp, 1956, p. 269). El eco polémico del discurso, en Devoto: Nacionalismo, fascismo y tradicionalismo en la Argentina Moderna, pp. 143-149, quien en p. 147 nota 79 advierte el parelelismo entre el pensamiento de Lugones y el de Maeztu en su común autoliberalismo y en la difusión de un espíritu regeneracionista (uno inspirado en Sarmiento y el otro en Costa) basado en la educación.

20 GÁlveZ, Manuel: «Interpretación de las dictaduras», en Criterio, no 32, 1-X-1928. Muchos años después, Gálvez seguía ensalzando el sentido práctico del general Primo de Rivera, cuya 
Fue en esta época cuando a la generación autoritaria de los años 80-90 se unieron los nacionalistas católicos de la generación posterior: Rodolfo y Julio Irazusta, Ernesto Palacio, Juan E. Carulla, Bruno Jacovella, Juan P. Ramos o Tomás D. Casares. Fue un grupo que reconoció explícitamente la influencia de l'Action Française (aunque marcó distancias con ella tras su condena por el Vaticano a fines de $1926^{21}$ ), y que no se apoyó en el nacionalismo católico más allá de ciertos límites. Para esta tendencia, la esencia de la nacionalidad no se deducía de dogmas abstractos y atemporales de corte filosófico y teológico, sino del análisis racional de la tradición patria concreta. Inspirados muchos de ellos en el «empirismo organizador» maurrasiano, sostenían que del estudio de la historia apoyado en fuentes documentales surgiría de forma natural la crítica a la democracia moderna y la demostración de la superioridad del ordenamiento social y político católico-tradicionalista. En su libro La Historia falsificada (Buenos Aires, Difusión, 1939), Palacio atacaba la herencia histórica liberal y denunciaba la deshispanización del país tras la independencia. Según Palacio, lo único real y básico de la nacionalidad argentina pertenecía a España, a la que se debían la religión y el idioma. Argentina debía retornar a sus tradiciones hispánicas y católicas, destruir el mito liberal contra Juan Manuel de Rosas y reivindicar sus ideales, protegiendo al país de influencias y dominaciones extranjeras, en especial la judía.

Como en Francia o en España, los nacionalistas autoritarios argentinos surgidos hacia 1925 como fuerza intelectual fueron siempre un grupo minoritario y dividido en tendencias que tenían mucho de conflicto generacional. Se aglutinaban en torno a publicaciones como La Nueva República (1927-1932), que rechazaba de la «demagogia democrática» y propugnaba una república autoritaria basada en el orden, la jerarquía, la autoridad y la restauración de la cultura católica. Esta derecha tradicionalista, fruto del revival del catolicismo intelectual a fines de la década de los veinte, se vinculaba a autores contrarrevolucionarios españoles como Juan Donoso Cortés, Jaime Balmes, Marcelino Menéndez y Pelayo o Juan Vázquez de Mella. En el ámbito inglés, entre los autores más citados figuraban los católicos Gilbert Keith Chesterton, Hillaire Belloc y, entre ciertos nacionalistas, el atípico filósofo hispano-británico George Santayana. También fue significativa la incidencia intelectual de filósofos de la historia como Nicolai Berdiaeff, Oswald Spengler y José Ortega y Gasset, todos ellos

\footnotetext{
dictadura moderada habría posibilitado la realización de una gran obra de progreso (GÁLVEZ, Manuel: España y algunos españoles, Buenos Aires, Ed. Huarpes, 1945, p. 92). Sobre el matizado filofascismo de Gálvez, identificado con un autoritarismo populista paliativo para los problemas derivados de la irreversible irrupción de las masas en la escena política (Este pueblo necesita..., Buenos Aires, García Santos, 1934), vid. HalPerín Donghi, Tulio: La Argentina y la tormenta del mundo. Ideas e ideologías entre 1930 y 1945, Buenos Aires, Siglo XXI Editores Argentina, 2003, pp. 42-47.

${ }^{21}$ GonZález Cuevas, Pedro Carlos: Acción Española. Teología política y nacionalismo autoritario en España (1913-1936), Madrid, Tecnos, 1998, p. 110 y Zuleta Álvarez, Enrique: El nacionalismo argentino, Buenos Aires, Eds. La Bastilla, 1975, vol. I, pp. 213-214.
} 
elitistas y difusores de la idea del hundimiento de la sociedad contemporánea, marcada por la crisis de la vieja aristocracia y de la vitalidad burguesa. Las líneas maestras del proyecto de La Nueva República eran la denuncia de la democracia liberal, la crítica del romanticismo, la transformación de la República en sentido autoritario y corporativo, la descentralización regional y municipal, la confesionalidad católica y el antiimperialismo ${ }^{22}$. Más cercanos al catolicismo social que al corporativismo fascista, exhibían también un virulento antisemitismo fundado en argumentos culturales, religiosos y políticos.

En realidad, las diferencias entre ambas generaciones nacionalistas eran de matiz. Compartían las mismas ideas antidemocráticas, elitistas, anticomunistas y católicas, además de una concepción corporativa del Estado. Denunciaban la dependencia argentina respecto de los países anglosajones sin que ello supusiera un ataque frontal al capitalismo, y en esa línea de crítica antiimperialista, encontraron en el hispanismo el ingrediente básico de la identidad nacional ${ }^{23}$. Para monseñor Franceschi, «la filosofía española, desde Séneca hasta Balmes, será escuela perenne de sabiduría, un arte de vivir, un campo sin límites de experiencias vitales, de disciplinas prácticas, de creaciones íntimas» ${ }^{24}$. De Menéndez Pelayo tomaron la idea de la Iglesia como representante histórica de la nacionalidad, y el mito palingenésico del espíritu apostólico y guerrero desplegado en la conquista de América en la época de los Austrias, que creó «un mundo hispánico aparte, con residencia propia en el espacio conquistado cuyo dominio correspondía al pueblo que lo habitaba. Esa relación de dominio es lo que constituye la soberanía, la autonomía, la independencia política de un pueblo» ${ }^{25}$. El mito de esta arcadia autosuficiente, destruida por el degenerado centralismo preliberal de los Borbones, debía ser revitalizado en un proyecto de unidad de los pueblos iberoamericanos, donde el catolicismo garantizase la armonía y la solidaridad sociales y un máximo en materia de bien común. Los nacionalistas personificaron en la dictadura de Juan Manuel de Rosas este régimen autocrático, autóctono y paternalista que aspiraban para Argentina ${ }^{26}$.

${ }_{22}$ El pensamiento político nacionalista, vol. I: De Alvear a Yrigoyen, Antología seleccionada y comentada por Julio IRAZUSTA, Buenos Aires, Obligado, 1975, pp. 55-56. Sobre La Nueva república, Vid. Devoto: Nacionalismo, fascismo y tradicionalismo en la Argentina moderna, pp. 159-188 y MUTSUKI, Noriko: Julio Irazusta. Treinta años de nacionalismo argentino. Buenos Aires, Biblos, 2004, pp. 56-60.

${ }_{23}$ BuCHrucker, Cristián: Nacionalismo y peronismo. La Argentina en la crisis ideológica mundial, 1927-1955, Buenos Aires, Sudamericana, 1987, pp. 123 ss.

${ }^{24}$ Criterio, 30-IV-1931, cit. por ROCK, David: La Argentina autoritaria. Los nacionalistas, su bistoria y su influencia en la vida pública, Buenos Aires, Ariel, p. 31.

25 IbARguren, Carlos (hijo): Roberto Laferrère: Periodismo-Politica-Historia, Buenos Aires, Ed. de la Universidad de Buenos Aires, 1970, p. 90.

${ }_{26}$ RoCK: La Argentina autoritaria, p. 131. 


\section{EL IMPACTO DE LA EMBAJADA DE MAEZTU SOBRE EL HISPANISMO TRADI- CIONALISTA ARGENTINO}

La segunda mitad de los años veinte contempló un auge inusitado de las vanguardias literarias en España, que pronto expresaron su voluntad de hegemonía en el mundo hispanoparlante. Un buen ejemplo de este impulso renovado fue la polémica que suscitó en Argentina un llamativo artículo de Guillermo de Torre en La Gaceta Literaria donde hablaba de «considerar el área intelectual americana como una prolongación del área española» ${ }^{27}$. Esta reactivación de las relaciones con el Nuevo Continente tuvo también su plasmación en un reforzamiento de la estructura diplomática, encabezada en ocasiones por conspicuos representantes de la intelectualidad finisecular de vocación hispanista. La estancia de Ramiro de Maeztu como embajador en la Argentina resultó un hecho decisivo para la formulación y proyección del nacionalismo contrarrevolucionario español en América, ya que su destino diplomático le sirvió para madurar su gran obra sobre la misión ecuménica de la raza hispánica encargada de dirigir a la Humanidad hacia la salvación ${ }^{28}$.

Firma habitual en los diarios argentinos - colaboró en Criterio y Crisol, y en La Prensa desde 1905 hasta su muerte violenta en 1936-, el escritor vitoriano no era un desconocido al llegar a Buenos Aires. Su posición ante la realidad socioeconómica del subcontinente americano permanecía influida por el ethos productivista que fue asimilando durante sus viajes a Gran Bretaña y los Estados Unidos. Tras la Gran Guerra advirtió que, a diferencia de Norteamérica, los países sudamericanos habían sido colonizados por gentes procedentes de zonas de predominio latifundista, cuya realidad vital no favorecía una concepción racionalizada de la vida económica y social. Las naciones sudamericanas habrían heredado de la España feudal un concepto y mentalidad «sensual» de la riqueza. En ese sentido, criticó la mentalidad precapitalista y antiutilitarista del «arielismo», que contraponía el espíritu idealista de la latinidad y el pragmatismo materialista anglosajón Apostaba por dar a la vida económica latinoamericana un «sentido reverencial del dinero» que facilitase el desarrollo de

27 TORRE, Guillermo de: «Madrid, meridiano intelectual de Hispanoamérica», en La Gaceta Literaria (Madrid), $\mathrm{n}^{\circ}$ 8, 15-IV-1927, p. 1, respondido por la revista vanguardista bonaerense en «¿Madrid, meridiana intelectual de Hispano-América?» y "A los compañeros de La Gaceta Literaria», en MArTín FiERro (Buenos Aires), no 42, 31-VIII-1927, pp. 6-7 y no 44-45, 15-XI-1927, pp. 9-11, respectivamente, y comentado en el editorial "La verbena del meridiano», en La Gaceta Literaria (Madrid), $\mathrm{n}^{\circ} 18,15-\mathrm{IX}-1927$, p. 1.

28 Sobre la estancia de Maeztu en la Argentina, véase FigALlo, Beatriz J.: «Ramiro de Maeztu y la Argentina», en Res Gestae (Rosario), no 24, julio-diciembre 1988, pp. 73-92 e "Yrigoyen y su segundo gobierno vistos por Ramiro de Maeztu», en Todo es historia (Buenos Aires), no 312 , julio 1993, pp. 80-93; OCIO, Luis: «La configuración del pensamiento reaccionario español: el caso de Ramiro de Maeztu durante su etapa de embajador en la Argentina», en Historia Contemporánea (Bilbao), no 18, 1999, pp. 347-382 y ZuletA: España en América, pp. 297-307. 
la mentalidad empresarial, y postulaba la ordenación jerárquica de la sociedad contra la «ferocidad igualitaria» ${ }^{29}$.

Su decisión de colaborar en la obra político-cultural de la Dictadura en el exterior obedeció a motivos de índole estrictamente patriótica. En un artículo publicado en La Prensa poco después del golpe de Estado, explicaba al público argentino las razones que justificaban la intervención de «cirugía política» de las Fuerzas Armadas en contra de los partidos políticos y la «corrupción democrática», como garantía de unidad frente a la amenaza disolvente del separatismo y el sindicalismo ${ }^{30}$. El funcionalismo conservador de su época londinense se convirtió, tras su inmersión en el hispanoamericanismo argentino, en un neotradicionalismo que giraría hasta su muerte alrededor del mito de la Hispanidad $^{31}$. Inmerso en esa trayectoria antirrevolucionaria, Pedro Sáinz Rodríguez, su avalista para el puesto diplomático, consideraba que Maeztu, convencido neófito del nacionalismo conservador, extendería con eficacia el menendezpelayismo y el pensamiento tradicional españoles a través de sus artículos y sus intervenciones públicas ${ }^{32}$.

Maeztu fue nombrado el 16 de diciembre de 1927, y antes de arribar a Buenos Aires tuvo ocasión de pronunciar una conferencia en Montevideo que mereció este despiadado comentario del rotativo El Día:

«Es verdaderamente lamentable que usted haya aprovechado los pocos minutos que le fue dado estar en nuestra tierra para herirnos en nuestros más caros sentimientos de hombres libres. Cuando se llega a un país como el nuestro, sobre todo de pasada, no se puede sin cometer una indiscreción imperdonable, hablar de ciertas cosas ya juzgadas y repudiadas, cuya sola enumeración y elogio provoca muy naturales reacciones. Ha pronunciado usted un brindis del más puro cuño loyolesco, que el gran Unamuno consideraría como una obra maestra de trogloditismo. Ha nombrado usted a Rodó y ha tenido para él frases ditirámbicas, a pesar de haber combatido en artículos que no conocemos muy bien, sus doctrinas de Ariel. Y en esta peligrosa pendiente, ha creído usted posible mezclar a Atenas con Jerusalén y Roma, para ofrecerlo después como un milagroso cocktail a España y América. Por suerte no habrá quien sea capaz de beber el bálsamo de Fierabrás en que usted quiere hacer compenetrar el paganismo sereno y alegre de la Hélade, a la tristeza y resignación semítica y a no sabemos si a la Roma de Pío XI o de Mussolini... Usted quizás crea posible que América pueda aceptar tales tutorías humillantes, pero eso es porque usted no conoce ni imagina siquiera lo que es América. No es posible felicitarlo por este su primer traspiés diplomático, que tiene necesariamente que restarle la simpatía de todos aquellos que no necesitan

29 MaEzTU, Ramiro de: Norteamérica desde dentro, Madrid, Editora Nacional, 1957, pp. 256-257.

30 MAeztu, Ramiro de: «El Ejército en España. El peligro de la balcanización», en La Prensa, 4-X-1923. También en MAEZTU, Ramiro de: Con el Directorio militar, Madrid, Editora Nacional, 1957, p. 21.

31 OCIO: «La configuración del pensamiento reaccionario español», p. 382

32 SÁINZ RodrígueZ, Pedro: Testimonio y recuerdos, Barcelona, Planeta, 1978, p. 153. 
para andar de andadores, ni de dogmas ni amos para pensar y obrar. Donde ya aparece inevitable el fracaso de su misión y de su propaganda, porque nadie estará aquí dispuesto a dejarse colocar los velos que usted nos trae. Esta es la tierra de la libertad, y porque conocemos muy bien sus ventajas y no ignoramos los inconvenientes de su falta, estamos decididos a no dejárnosla arrebatar. Si con tales ideas piensa usted trabajar en pro del acercamiento entre España y América, siga nuestro consejo: embárquese de vuelta porque su acción será contraproducente o estéril. Sus palabras prueban nuestra sospecha: que usted no es embajador de un pueblo sino de un régimen impuesto y mantenido a la fuerza; representante de un hombre o de una institución, no de una nación.

Desgraciadamente para usted, su debut no pudo ser más desventurado. No puede explicarse cómo a sus años y con su fama de filósofo ha olvidado usted la sabiduría del adagio popular que dice: 'a buen callar llaman Sancho'»33.

Maeztu presentó sus cartas credenciales el 20 de febrero de 1928, en el momento en que se daba en el país un cierto auge del tradicionalismo ideológico y del pensamiento católico integrista en publicaciones como La Nueva República, con cuyos redactores - especialmente con Ernesto Palacio- trabó una sólida $\operatorname{amistad}^{34}$. Se estableció así una corriente de mutua influencia, fundamentada en la crítica a la democracia liberal, la valoración del catolicismo como principal componente de las respectivas identidades nacionales y el deseo de renacimiento de la tradición cultural hispana ${ }^{35}$. Gracias su relación con el grupo liderado por los hermanos Irazusta, Maeztu profundizó en los clásicos del pensamiento tradicionalista español y europeo, como la obra del dominico Juan González Arintero. Por su parte, los colaboradores de La Nueva República coincidían con el embajador español en la misión política que debían desempeñar los escritores, aunque éste no apoyaba a los nacionalistas en su cerrada hostilidad al declinante gobierno de Yrigoyen. Existía además una teórica contradicción entre la lucha antioligárquica y antiimperalista preconizada por ese grupo y el imperialismo elitista y espiritualista propugnado en esos momentos desde España. La conferencia de Maeztu sobre «La beneficencia y el capitalismo», pronunciada en la aristocrática Sociedad de Beneficencia, supuso un nuevo intento de divulgar su tesis sobre el sentido reverencial del dinero y de postular el desarrollo de un capitalismo nacional fuerte ante la expansión imperialista norteamericana y británica. Trataba de demostrar que el empleo del ahorro en

33 Cit. por Perucho, Artur: Catalunya sota la Dictadura (Dades per a la Història), Barcelona, Eds. Proa, 1930, pp. 202-204. Por su parte, Nosotros de Buenos Aires señalaba que «ciertamente las tareas a que últimamente se ha dedicado el ilustre escritor vasco no son los mejores títulos que pueden ostentarse para representar dignamente a España ante la Argentina».

${ }^{34}$ La relación de Maeztu con el grupo de La Nueva República, en MARrero, Vicente: Maeztu, Madrid, Rialp, 1955, pp. 245-258. Sobre su estancia en Argentina, véase también ZulETA ÁlvareZ, Enrique: «Maeztu en Buenos Aires», en Razón Española, no 83, mayo-junio 1997, pp. 319-325.

35 Vid. Irazusta, Julio: «Ramiro de Maeztu», en Actores y espectadores, Buenos Aires, Julio Dictio, 1980, pp. 187 ss. 
el mejoramiento de la producción era uno de los modos más elevados de beneficencia, pues llevaba implícito la demanda de trabajo y la elevación de los salarios $^{36}$. Ello sintonizaba con los llamamientos de ciertos intelectuales como Irazusta de emancipar a Argentina de la dependencia económica anglosajona, pero su propuesta de adaptación de la ética asistencial católica a las premisas del desarrollo económico sólo tuvo eco en los ambientes más aristocráticos de la sociedad bonaerense.

Más consecuencias para el futuro tuvo su relación con el padre Zacarías de Vizcarra y Arana (1879-1963), sacerdote procedente de la Universidad de Comillas, estrechamente vinculado a la colectividad española y muy activo en la propagación polémica del catolicismo y el tradicionalismo. Vizcarra era presidente de la Asociación del Clero Español, y fundador de la Cátedra Cultural Isidoriana para la formación de la juventud, del Centro de Estudios Religiosos para Señoritas, del Instituto Greco-Técnico y de un conjunto de escuelas de periodismo. Intervino igualmente en la fundación del Centro de Acción Española en Buenos Aires y en la revista católica Criterio, que bajo la dirección de Atilio Dell'Oro Maini y bajo el patrocinio del Episcopado de Buenos Aires se transformó en el portavoz de la tendencia nacional, católica y antiliberal del clero argentino ${ }^{37}$. También era profesor de los Cursos de Cultura Católica para Universitarios creados en Buenos Aires en 1922 por César E. Pico y Dell'Oro Maini dentro de programa renovador del peAsamiento católico, que permitió la formación de un clero más combativo y decididamente antiliberal, que logró conciliar el tomismo con el pensamiento conservador clásico y con autores heterodoxos como Berdiaeff, Maurras, Bainville o Spengler ${ }^{38}$. Maeztu conversó frecuentemente con los participantes de estos cursos, y muchas de las ideas expuestas en Defensa de la Hispanidad surgieron al parecer de estas sesiones ${ }^{39}$.

36 MaezTU, Ramiro de: «La beneficencia y el capitalismo», en El Diario Español, 6-X-1928. También pronunció una conferencia en el no menos elitista Jockey Club el 18 de abril de 1928 sobre el Quijote, donde glosó «la existencia del común ideal de los pueblos hispánicos, formado por la cultura y creencias del siglo XVI».

37 Sobre Criterio como revista prototípica del catolicismo integrista, vid. DEvoTO: Nacionalismo, fascismo y tradicionalismo en la Argentina moderna, pp. 206-234; ZANATTA, Loris: Del Estado liberal a la nación católica. Iglesia y ejército en los orígenes del peronismo, 1930-1943, Bernal, Universidad Nacional de Quilmes, 1996, pp. 46-50 y 133-134 y RAPALO, María Ester: «La Iglesia católica argentina y el autoritarismo político: la revista criterio, 1928-1931», en Anuario del IEHS (Tandil), n 5, 1990, pp. 51-70 y «De la Asociación del Trabajo a la revista Criterio: encuentros entre propietarios e ideólogos, 1919-1929», en VV.AA.: La derecha argentina. Nacionalistas, neoliberales, militares y clericales, Buenos Aires, Eds. B Argentina, 2001, pp. 139-144.

38 ZANATTA: Del Estado liberal a la nación católica, pp. 30, 45, 114-116. En estos cursos se formaron figuras del nacionalismo como Mario Amadeo, Héctor Llambías, A. Ezcurra, Mario Etchecopar, Juan Carlos Goyeneche, José María de Estrada o Federico Ibarguren.

39 La Nueva República, n $\mathrm{n}^{\mathrm{7}}$, 1-III-1928, cit. por MCGEE DEUTSCH, Sandra: Counterrevolution in Argentina, 1900-1932. The Argentine Patriotic League, Lincoln y Londres, University of Nebraska Press, 1986, p. 197. 
Vizcarra confesó que Maeztu le consultaba sobre cuestiones de teología y de ortodoxia católicas ${ }^{40}$. Sin embargo, le atribuyó erróneamente la paternidad del término «Hispanidad», cuando desde principios de siglo era admitido en el diccionario de la Real Academia Española como sinónimo de hispanismo o peculiar modo de hablar el español fuera de las reglas castellanas. También es conocido que el primer intelectual en utilizarlo, si bien en un sentido muy diferente, fue Miguel de Unamuno, que empleó este vocablo en 1909 como sinónimo de proyecto cultural de impronta liberal compuesto por una amalgama de razas y culturas en un espacio geográfico en el que España se vinculaba a la totalidad de la comunidad hispánica, de esencia fundamentalmente lingüística. Para Unamuno, sólo una confederación espiritual de esta índole podría dar seguridad, bienestar y progreso a España y América, una vez garantizadas las independencias nacionales ${ }^{41}$.

Vizcarra, que en esos momentos llevaba desde El Eco Español una campaña de proselitismo hispanista par proclamar el 12 de octubre «Día de la Hispanidad», conocía sin duda el artículo de Unamuno, pero en 1926 trató de añadir dos nuevas acepciones: una geográfica que designaba el conjunto de todos los pueblos hispanos, y otra ético-espiritual que debía definir el conjunto de cualidades que distinguían a estos pueblos ${ }^{42}$. De este modo, trascendió la identidad lingüística de la idea unamuniana, dándola una dimensión espiritual católica, que Maeztu utilizaría en sus informes diplomáticos con el significado de comunidad espiritual de los pueblos hispanos. Vizcarra destacó la misión providencial que debía reemprender España con la construcción teórica de un «ideal hispánico» impulsado por los «nuevos caballeros de Santiago», concepción cuasi-mística de la acción de minorías que tras ser asumida por José Antonio Primo de Rivera a través de Ortega y Gasset, formaría parte de la táctica políticopropagandística de Falange Española en el exterior.

Las conferencias pronunciadas por Maeztu en Bahía Blanca en enero de 1929 y en el Centro Gallego de Montevideo cuatro meses después, que fueron publicadas bajo el título genérico de «El Espíritu de la civilización española»,

40 VizCARRA, Zacarías de: «La rectitud de Don Ramiro», en Cuadernos Hispanoamericanos (Madrid), no 33-34, septiembre-octubre 1952, pp. 15-16.

41 Unamuno, Miguel de: «Sobre la argentinidad», en Temas argentinos, Buenos Aires, Institución Cultural Española, 1949, p. 63. Sobre los orígenes del término «Hispanidad», véase ARCO Y GARAY, Ricardo del, La idea del imperio en la política y literatura españolas, Madrid, EspasaCalpe, 1944, p. 787; GonZÁlez Cuevas, Pedro Carlos: «Hispanidad», en Blas Guerrero, Andrés de (dir.): Enciclopedia del Nacionalismo, Madrid, Tecnos, 1997, pp. 215-219; PARDo SANZ, Rosa María: iCon Franco hacia el Imperio!. La política exterior española en América Latina, 1939-1945, Madrid, UNED, 1995, pp. 215-219 y PIKE: Hispanismo, p. 59.

42 VizCARra, Zacarías de: «El apóstol Santiago y el mundo hispano», en Acción Española (Madrid), $\mathrm{n}^{\circ} 15$, agosto 1932, pp. 384-400. Es un resumen de las tesis expuestas en su obra La vocación de América, Buenos Aires, Gladius, 1995 ( $1^{\text {a }}$ ed. de 1926). Vizcarra acabó asesorando a Acción Católica en la España franquista (BOTTI, Alfonso: Cielo y dinero. Los orígenes del nacional-catolicismo español, Madrid, Alianza, 1992, pp. 82-83). 
acabarían formando el embrión del capítulo sobre «El sentido del hombre en los pueblos hispánicos» de su obra Defensa de la Hispanidad. Maeztu renunció a la Embajada el 19 de febrero de 1930, no sin antes haber intentado en vano la creación de unas «uniones patrióticas» teóricamente «apolíticas» entre los emigrantes españoles en la república ${ }^{43}$. Durante ese año y el siguiente siguió escribiendo artículos filosóficos y sobre la situación política española en la revista católica Criterio, donde tras advertir un inquietante paralelismo entre la crisis española que desembocó en la proclamación de la República y la incertidumbre de las elecciones previstas en Argentina para noviembre de 1931, propugnaba un régimen autoritario de inequívoca identidad católica que se erigiese en dique frente a la inminente revolución, y donde los militares actuasen como élite alternativa a la crisis de las clases dirigentes tradicionales ${ }^{44}$.

La evolución política e intelectual de Maeztu durante la Segunda República resulta indisociable del proyecto cultural de Acción Española, publicación abanderada de la revisión histórico-doctrinal del nacionalismo contrarrevolucionario español de los años treinta, a través de la divulgación de los clichés, imágenes y valores de la España de la Contrarreforma que debían de erigirse en el acervo cultural, no sólo de una nación que buscaba su resurgimiento, sino también de un mundo «regenerado» de su materialismo.

\section{El NaCionalismo en la CRisis de LOS AÑOS TReinta}

El año 1930 contempló un giro inesperado en la evolución política de España y Argentina. En enero, la caída de la Dictadura primorriverista estimuló el esfuerzo de movilización democrática que acabaría en la proclamación de la República quince meses después. El 6 de septiembre, el derrocamiento de Yrigoyen marcó el final de la primera experiencia democrática de masas de la historia argentina, y el comienzo de la época «clásica» de influencia de la «revolución conservadora» ${ }^{45}$.

El papel del nacionalismo en el golpe de Estado de septiembre fue irrelevante, y, según la cuestionable interpretación de Zuleta, marcó aún más su disociación en dos tendencias: un nacionalismo restaurador, tradicionalista y aristocrático, y un nacionalismo «republicano» con rasgos antioligárquicos y antiimperialistas. El general Uriburu se habría apoyado en la primera corriente, doctrinaria, militarista, oligárquica, antimodernista y contrarrevolucionaria,

43 Primo de Rivera a Maeztu, 14-IV-1928, en Archivo del Ministerio de Asuntos Exteriores, Madrid (en adelante AMAE), leg. R-1302.

${ }_{44}$ MaEzTU, Ramiro de: «La necesidad de la Monarquía Militar», en Criterio (Buenos Aires), 21-IV-1931. También en MAEZTU, Ramiro de: Liquidación de la Monarquía parlamentaria, Madrid, Editora Nacional, 1957, pp. 197-202. En esa misma época, Gálvez propugnaba a ambos lados del Atlántico un gobierno dictatorial conservador («Ignorancia, república, comunismo», en Criterio, 13VIII-1931).

45 BUCHRUCKER: Nacionalismo y peronismo, p. 163. 
que trató de llenar el vacío dejado por la vieja clase dirigente conservadora. Estos nacionalistas, como Leopoldo Lugones y Carlos Ibarguren (primo del general), eran partidarios de una dictadura aristocratizante que forjara un Estado corporativo inspirado en el fascismo, con base en el orden, la autoridad y la jerarquía ${ }^{46}$. El propio ideario de Uriburu era una crítica despiadada de las instituciones democráticas y de la concepción liberal del mundo representada en la «demagogia yrigoyenista» ${ }^{47}$. Admirador confeso de la obra de Primo de Rivera, buscó la colaboración de entes no partidarios de movilización inspirados en la Unión Patriótica, como la Liga Republicana (autodefinida como «liga de acción» y «milicia voluntaria» dirigida contra «los enemigos interiores de la República»), la Legión de Mayo (fundada el 25 de agosto de 1930 por el diputado conservador Alberto Viñas sobre la base de la Liga Republicana) y la Liga Patriótica Argentina presidida hasta su muerte en 1946 por el radical antipersonalista Manuel Carlés, que había sido fundada durante la crisis de 1919 bajo el modelo de la Ligue des Patriotes francesa ${ }^{48}$. La imitación mimética con la Dictadura española avanzó aún más cuando el 20 de mayo de 1931 un decreto de la Presidencia de la República creó la Legión Cívica, una «unión cívica» remedo del Somatén Nacional primorriverista que por unos años fue el centro de actividad nacionalista. La Legión Cívica desplegó una retórica nacionalista y gubernamentalista muy cercana a la de su modelo español. Era una «asociación de hombres patriotas que moral y materialmente están dispuestos a cooperar en la reconstrucción institucional del país», y su misión era «colaborar con las autoridades en el mantenimiento de la seguridad y del orden interno, y trabajar por el afianzamiento de la argentinidad y por el culto de la patria, luchando contra todo acto que atente contra la unidad social y moral del pueblo argentino» ${ }^{49}$. En todo caso, la paramilitarización de la vida política bajo la inspiración

46 Sobre el filofascismo de Carlos Ibarguren como medio para la restauración de la élite política desplazada por la Ley Sáenz Peña de 10-II-1912 (La inquietud de esta hora. Liberalismo corporativismo, nacionalismo, Buenos Aires, La Facultad, 1934), vid. HALPerín DONGHI, Tulio: La Argentina y la tormenta del mundo. Ideas e ideologías entre 1930 y 1945, Buenos Aires, Siglo XXI Editores Argentina, 2003, pp. 35-41.

47 BUCHRUCKer: Nacionalismo y peronismo, p. 53.

48 Sobre los orígenes de esta Liga, vid. Devoto: Nacionalismo, fascismo y tradicionalismo en la Argentina moderna, pp. 126-138. MCGEE DeUTSCH: Counterrevolution in Argentina, pp. 82-111.

${ }_{49}$ Del texto del decreto, cit. por PuIGgrós, Rodolfo: Historia crítica de los partidos políticos argentinos, Buenos Aires, Hispamérica, 1986, vol. III, p. 19, y DíAZ, Claudio y ZuCCO, Antonio: La ultra derecha argentina y su conexión internacional, Buenos Aires, Ed. Contrapunto, 1987, p. 34. Según su programa, publicado en 1932, la Legión se proponía defender los objetivos de la «revolución» de 1930: corporativismo, reforma constitucional, reglamentación de la inmigración, prohibición de cargos públicos para los no nacidos en el país y reparto de la propiedad. Sobre la Legión Cívica Argentina, vid. BuCHRUCKER: Nacionalismo y peronismo, pp. 90-91 y MCGEE DeUTSCH: Counterrevolution in Argentina, pp. 209-216 y «The Visible and Invisible Liga Patriotica Argentina, 1919-28: Gender Roles and the Right Wing», en Hispanic American Historical Review (College Park, MD), vol. 64, $\mathrm{n}^{\circ}$ 2, mayo 1984, pp. 233-258. 
de ejemplos foráneos como el squadrismo fascista resultó un hecho característico de esta nueva etapa autoritaria: en 1932, Roberto de Laferrère reconstituyó su Liga Republicana con grupos semimilitares concentrados en una "guardia de combate», y Juan P. Ramos también creó en junio de 1932 una Acción Nacionalista Argentina que en 1936 buscaba un general para el desencadenamiento de un golpe de Estado. Como señala Buchrucker, «el nacionalismo restaurador no puede ser explicado, en numerosos aspectos importantes de su desarrollo, ideología y organización, sin tomar en cuenta la función paradigmática que tuvieron para ese movimiento los modelos europeos» ${ }^{50}$. Pero en la Argentina, más que el nazismo prevaleció un ultratradicionalismo católico cercano al modelo franquista o al «austrofascismo» de Dollfuss.

Dentro del nacionalismo doctrinario favorable al régimen autoritario destacaron varios hispanistas tradicionalistas vinculados con el padre Julio Meinvielle, como A. Ezcurra Medrano, J.C. Villagra, Juan Carlos Goyeneche, Mario Amadeo y Héctor Sáenz de Quesada, que animaron revistas como Baluarte, Número, Heroica, Crisol (ámbito de reunión de agrupaciones e independientes simpatizantes del nacionalismo, dirigido por Enrique P. Osés y con 4.000 ejemplares de tirada) o Sol y Luna (1938-43), dirigida por Juan Carlos Goyeneche, Mario Amadeo y José María de Estrada, grandes figuras del pensamiento católico, hispanista y nacionalista, que promocionaron intensamente la producción cultural procedente de la España nacionalista ${ }^{51}$. Otras publicaciones destacadas de esa tendencia fueron Ortodoxia (órgano de las Cursos de Cultura Católica), El Fortín (vocero de la Liga Republicana entre 1940-43, con unos 5.000 ejemplares de tirada), la pronazi Bandera Argentina (dirigida por Juan E. Carulla desde su fundación el $1^{\circ}$ de agosto de 1932 y que alcanzaría los 7.000 ejemplares), El Pampero (luego El Federal, con 75.000 ejemplares de venta), Ofensiva y Choque. La mejor revista de esta tendencia era Nueva Política (1940-43), dirigida por Marcelo Sánchez Sorondo con la colaboración de Federico Ibarguren, Ignacio B. Anzoátegui, Máximo Etchecopar, Hector Saenz y Quesada, Nimio de Anquín, Juan Pablo Oliver, etc. Los tradicionalistas doctrinarios trataban de restaurar los valores tradicionales que el liberalismo había vulnerado, sobre todo la tradición hispánica y católica ${ }^{52}$. Desplegaron una visión maniquea de la historia, marcada por la evocación nostálgica de la Edad Media y del Imperio español, que envolvía una crítica explícita a la modernidad ${ }^{53}$. Pero al hilo de la transformación del régimen liberal argentino en un sentido

50 BUCHRUCKER: Nacionalismo y peronismo, p. 271.

51 Entre los colaboradores españoles se encontraban José Ma Pemán, Eugenio Montes, Eugenio d’Ors, Juan José López Ibor y María de Maeztu. Véase Quiroga Fernández DE Soto, Alejandro: «La revista Sol y Luna y el nacionalismo argentino», en Cuadernos Hispanoamericanos (Madrid), $\mathrm{n}^{\circ}$ 611, mayo, 2001, p. 68 nota 3.

52 Para IBARguren, Federico: Orígenes del nacionalismo argentino, 1927-1937, Buenos Aires, Celsius, 1970, p. 13, la «tradición hispano-federal» era la base del nacionalismo argentino en 1930.

53 BUCHRUCKER: Nacionalismo y peronismo, pp. 166-168. 
claramente autoritario, la influencia del pensamiento católico tradicional español fue dejando paso a aportaciones más renovadoras procedentes de la derecha radical, el monarquismo antiliberal y el fascismo, que en la Península lograron un apreciable eco cultural en su oposición a la Segunda República.

La otra tendencia es la que Zuleta designa con el nombre de nacionalismo republicano, representado por Ernesto Palacio, Rodolfo Irazusta y la revista Nuevo Orden, con 3.000 ejemplares de tirada, que mantuvo una actitud pro-Eje desde julio de 1940 hasta junio de1942, en que fue sustituida por La Voz del Plata. Irazusta era partidario de una reforma profunda del Estado sobre bases antidemocráticas, antioligárquicas y antiimperialistas, como evidencia el libro publicado con su hermano Julio Argentina y el imperalismo británico. Los eslabones de una cadena, 1806-1933 (Buenos Aires, Tor, 193454), publicado como reacción al pacto Roca-Runciman de 1933 y primer paso de una reacción intelectual nacionalista contra los conservadores que desembocó en el revisionismo histórico aglutinado a partir de 1938 en el Instituto de Investigaciones Históricas Juan Manuel de Rosas (1938).

Aunque este grupo intelectual se mostraba de acuerdo con los nacionalistas doctrinarios en la crítica al liberalismo y en la restauración de los valores de cultura tradicional de raigambre hispánica y católica, rechazaban la inserción en el nacionalismo «oficialista» o en los partidos tradicionales (los liberales elitistas, partidarios de mantener formalmente el régimen parlamentario, acabaron por apoyar a Justo, fomentando un parlamentarismo residual de carácter oligárquico), eran enemigos de un filofascismo puramente cosmético, y frente al conservadurismo y el radicalismo reputados como extranjerizantes ofrecían una lectura nacional-populista y antiplutocrática mucho más cercana al fascismo real. Desde septiembre de 1942, el nacionalismo entró en crisis por las diferencias insalvables que se marcaron ante la toma de postura para la elección presidencial del año siguiente. Los días 11 y 12 de octubre, una convención nacionalista celebrada en Córdoba hizo surgir el Partido Libertador, que se desarrolló en Buenos Aires en 1943 y en Santiago del Estero y Mendoza en 1944, cuando se separó definitivamente de los grupos filofascistas.

La proclamación de la República Española, coincidente con el inicio de la «década infame», produjo también una evidente politización y polarización de la vida cultural argentina, donde la difusión del fascismo en Europa y el impacto de la guerra civil española permitieron subrayar la cuestión cultural en la definición del «ser nacional», en especial el catolicismo y el hispanismo5s. La influencia del

${ }_{54}$ Una aguda crítica de los límites del antiimperialismo de Julio y Rodolfo Irazusta, proclives más bien a una identificación del interés nacional con el interés terrateniente, en HALPERín DONGHI, Tulio: La Argentina y la tormenta del mundo, pp. 69-85. Vid. también MuTsuKi: Julio Irazusta, pp. 85101. Rodolfo Irazusta admiraba el doctrinarismo de Donoso Cortés. Vid. al respecto La Nueva República (Buenos Aires), $\mathrm{n}^{\circ}$ 15, 26-V-1928. Sobre el hispanismo de este intelectual, vid. Zuleta Álvarez, Enrique: «España en la obra de Irazusta», en Razon Española (Madrid), no 63, 1994, pp. 7-30.

55 ZULETA: El nacionalismo argentino, vol. I, pp. 13-14. 
nacionalismo autoritario español en Argentina siguió ese mismo derrotero, desde el influjo teórico en sectores minoritarios hasta a inicio de los años treinta hasta su impacto político más directo y masivo a partir de la guerra civil.

En el pensamiento contrarrevolucionario español, la identificación del Imperio con la Monarquía, y de ésta con la religión, sentó una de las bases de la rebeldía contra una República laica, pacifista y reconocedora de la realidad plurinacional de España. También se caracterizó por su oposición a toda tentativa de ralliement emprendida desde Acción Nacional (y posteriormente por Acción Popular y la CEDA) por Ángel Herrera, José María Gil Robles y un sector de la jerarquía católica representada por el nuncio Tedeschini y el cardenal Vidal y Barraquer. Sin embargo, otro sector de la misma se decantó inequívocamente por los valores de la Hispanidad expuestos en la revista doctrinal monárquica Acción Española, la más insistente divulgadora de una interpretación nacional-católica del vínculo de España con sus antiguas colonias. Uno de los exponentes más conocido y significativos de esta corriente hispanista reaccionaria fue la apología realizada por el cardenal primado Isidro Gomá y Tomás en el XXXII Congreso Eucarístico Internacional celebrado en Buenos Aires el 12 de octubre de 1934. El arzobispo de Toledo, que puso a los militares argentinos como modelo de cristiandad militante, desplegó en esa ocasión todo el elenco de conceptos anejos al ideario hispánico tradicionalista: providencialismo, identificación de España con el catolicismo como nexo universal de la cultura latina occidental; rechazo del comunismo y del liberalismo; afirmación de la superioridad de la cultura y la colonización hispánicas sobre la anglosajona; revalorización del espíritu netamente español de América, y unidad cultural que no excluía el estrechamiento de lazos económicos ${ }^{56}$.

Esa era la precisamente línea que seguía la revista Acción Española desde su misma fundación. Los intentos de proyección cultural hacia América fueron emprendidos desde el primer número por Ramiro de Maeztu en un escrito titulado «Hispanidad», y culminaron desde el número 5 con una larga serie de artículos sobre la Hispanidad, su defensa, su valor y su crisis ${ }^{57}$ que darían lugar en 1934 a Defensa de la Hispanidad, la obra donde apareció la formulación más completa de su ideario hispánico, asumido y glosado por algunos de los más destacados teóricos del fascismo español, y que gozaría de una innegable influencia en el mundo intelectual conservador latinoamericano en las décadas posteriores ${ }^{58}$.

56 GoMÁ Y TOMÁs, Isidro: «Apología de la Hispanidad», en Acción Española (Madrid), nº 64-65, noviembre 1934, y en $n^{\circ} 89$, marzo 1937, p. 20. También en GOMÁ y TOMÁs, Isidro: Antilaicismo, Barcelona, Rafael Casulleras, 1935, vol. II, pp. 30-31 y en la $2^{\text {a }}$ ed. de Defensa de la Hispanidad, Santander, Aldus, 1938, p. 329-333. Sobre la trascendencia del Congreso Eucarístico Internacional de octubre de 1934 como ensayo de catolización del sentimiento nacional argentino bajo el gobierno conservador de Justo, vid. ZANATTA: Del Estado liberal a la nación católica, pp. 155-163.

57 MaezTu, Ramiro de: «La Hispanidad», en Acción Española (Madrid), n ${ }^{\circ}$ 1, 1931, p. 12; «Hispanidad», ibid., n 5, 1932, pp. 449-450 y «La tradición hispánica de América», en ibid., nº 74, 1934, pp. 1-5.

${ }_{58} \mathrm{El}$ catolicismo hispanista difundido por Maeztu inspiró a numerosas figuras latinoamericanas, entre ellas el nicaragüense Pablo Antonio Cuadra; los peruanos Felipe Barreda Laos, Víctor Andrés 
Para Maeztu, el nacionalismo español rompía el dilema entre universalismo y particularismo gracias a su componente católico. La misión universal de España era la realización cristiana del ideal de Humanidad, que se objetivaba históricamente en la evangelización de América ${ }^{59}$. Bien es cierto que ese "destino universal» propiciado por una historia y unas creencias había de traducirse en una perfecta compenetración de los poderes temporal y espiritual a través de las idealizadas simbiosis teocráticas trono/altar y unidad nacional/unidad católica. El escritor vasco consideraba que la Hispanidad era la comunidad histórica de los pueblos hispánicos, pero también una Weltanschauung humanista basada en el espiritualismo católico, cuyo punto de partida era la unidad del género humano. La Hispanidad suponía, pues, una amalgama de los rasgos cristianos y humanistas de la identidad española proyectada hacia la acción exterior (en concreto a los pueblos de estirpe y cultura hispánicas), opuesta al racionalismo, el liberalismo y la democracia, a los que consideraba valores extranjerizantes e inadaptables a nuestra idiosincrasia. La Hispanidad se convirtió en un proyecto nacionalizador en cuanto la vertebración nacional debía lograrse mediante la consecución de ese destino o misión comunitaria hispánica, realización plena de un fin humano supranacional. Sin embargo, la «Defensa de la Hispanidad» emprendida por Maeztu no tenía connotaciones jurídicas o políticas. Era más bien un substrato cultural o espiritual que había de ser asumido de forma voluntaria por las naciones iberoamericanas superando las diferencias de raza, de geografía o de régimen político.

Siguiendo sintomáticamente las pautas de actuación política sugeridas por Maurras para la restauración monárquica en Francia, Maeztu propugnó una política de coordinación de intereses y objetivos de los pueblos hispánicos que quizás culminase en un estado de opinión favorable a una confederación voluntaria bajo moldes políticos tradicionales. Pero su mensaje, eminentemente histórico y cultural, no postulaba claramente la consecución de un imperio territorial ni combatía directamente el indigenismo. De forma que tuvo la virtud involuntaria de ser interpretado en los años siguientes de forma más o menos agresiva y excluyente por conspicuos representantes de la jerarquía católica o por destacados líderes del falangismo. El mito del Imperio y de la conquista y colonización de América, la defensa de las estructuras políticas y sociales anejas al mismo y los valores morales de la España tradicional anterior a la revolución liberal formarían, además, parte de los cimientos teóricos donde se apoyaría el nacionalcatolicismo como rasgo ideológico identificativo del futuro régimen franquista.

Belaúnde, José de la Riva Agüero y Alberto Wagner de Reyna, el ecuatoriano José María Velasco Ibarra, el argentino Mario Amadeo, los chilenos Víctor de Valdivia y Osvaldo Lira, el mexicano José Vasconcelos y el uruguayo Alberto de Herrera. Sobre esta influencia, véase Vegas LATAPIÉ, Eugenio: Romanticismo y democracia, Santander, Impta,. Aldus, 1938, pp. 180-181; MARTín ARTAJO, Alberto: Hacia la comunidad hispánica de naciones, Madrid, Cultura Hispánica, 1956 y MARRERO: Maeztu, pp. 474-495.

59 Maeztu, Ramiro de: Defensa de la Hispanidad. Prólogo de Eugenio Vegas Latapié. Epílogo del cardenal Isidro Gomá, $2^{a}$ ed., Santander, Aldus, 1938, p. 915. 
Ningún nacionalista argentino, a excepción del diplomático Roberto Levillier, colaboró en Acción Española, pero Defensa de la Hispanidad tuvo gran repercusión en la intelectualidad contrarrevolucionaria argentina de los años treinta, actuó como revulsivo frente al indigenismo y el panamericanismo, e incluso complementó la devoción maurrasiana gracias al papel dado al catolicismo ${ }^{60}$. Julio Irazusta comparó Defensa de la Hispanidad con el programa contrarrevolucionario reflejado en la Encuesta sobre la Monarquía de Maurras, pero con la ventaja de que no supeditaba el plan nacionalizador a la Monarquía, sino al «objeto universal de la evangelización del mundo». En su opinión, Maeztu «nos aclara ideas que nosotros habíamos pensado y nos da otras que no, reuniéndolas a todas en un sistema orgánico de admirable arquitectura» ${ }^{61}$. En su reseña de la obra maeztiana, Ernesto Palacio abogaba por una revisión de la historia que restaurara la tradición hispánica ${ }^{62}$.

El estallido de la Guerra Civil española se vivió en Argentina como un asunto propio. No sólo por la actitud beligerante en uno u otro sentido mostrada por la mayor parte de la colonia española ${ }^{63}$, sino porque los principios que se dirimían en la lucha tenían una directa incidencia en la política interna del país. Los liberales y los socialistas tomaron partido por la democracia republicana, mientras que los conservadores y los nacionalistas lo hicieron por la sublevación militar ${ }^{64}$. Desde Bandera Argentina, Crisol, Fronda o Clarinada, los nacionalistas

60 Navarro Gerassi, Marysa: Los nacionalistas, Buenos Aires, Jorge Álvarez, 1969, p. 125. Según Zuleta: España en América, p. 255, «la idea de que la Argentina debía recobrar su autenticidad aceptando el legado lingüístico y cultural español, el rescate de los valores del paisaje, la humanidad y la peculiaridad de regiones olvidadas, como lo había hecho magistralmente Azorín, la necesidad de restaurar el espiritualismo que superara el egoísmo y el materialismo de las clases dirigentes, la defensa, en fin, de la unidad hispanoamericana en torno a los valores de la lengua, la historia y los ideales tradicionales, no se podrían haber concebido fuera de la lección de un Maeztu, por ejemplo, pero el de Defensa de la Hispanidad»,

61 IRAZUSTA, Julio: «Un acontecimiento de la literatura política española: Defensa de la Hispanidad de Ramiro de Maeztu», en La Gaceta de Buenos Aires, n 1, 20-VII-1934, también en Actores y espectadores, $2^{\mathrm{a}}$ ed., Buenos Aires, Dictio, 1978, pp. 183 y 185-186 (1ª ed. de 1937).

62 PalaCiO, Ernesto: "Defensa de la Hispanidad, de Ramiro de Maeztu», en El Hogar (Buenos Aires), 21-XI-1934, p. 84.

63 Véase al respecto Delgado Gómez-EsCalonilla, Lorenzo, GonZález Calleja, Eduardo y GonZÁlez de OleAgA, Marisa: «La dinámica franquismo/oposición en Argentina: un ensayo de interpretación (1936-1950)», en Alted, Alicia, Tusell, Javier y MATEOS, Abdón (coords.): La oposición al régimen de Franco. Estado de la cuestión y metodología de la investigación, Madrid, UNED, tomo I, vol. 2, 1990, pp. 275-295; GOLDAR, Ernesto: Los argentinos y la guerra civil española, Buenos Aires, Ed. Contrapunto, 1986; MONTENEGRO, Silvina: La Guerra Civil Española y la política argentina, tesis doctiral, Madrid, Universidad Complutense, 2002; QuIJADA, Mónica: Relaciones hispanoargentinas, 1936-1946. Coyunturas de crisis, Madrid, Editorial de la Universidad Complutense, 1990 y Aires de República, aires de Cruzada: la Guerra Civil Española en Argentina, Barcelona, Sendai Ediciones, 1991 y TRIFONE, Víctor y SVARZMAN, Gustavo: La repercusión de la guerra civil española en la Argentina (1936-1939), Buenos Aires, Centro Editor de América Latina, 1993.

${ }^{64}$ Por ejemplo, el 16-VIII-1936 La Vanguardia publicó una declaración de escritores argentinos denunciando la destrucción de templos y la «dictadura soviética». Entre otros figuraban 
argentinos trataron de conseguir el reconocimiento del bando rebelde, confundiendo los temas del nacionalismo católico con el apoyo a Franco. Por ejemplo, Manuel Gálvez mostró su afinidad con el bando faccioso al considerar en peligro los conceptos «de la familia, de la moral y hasta de la dignidad de la mujer. Está en peligro nuestra religión católica. Está en peligro nuestro idioma, que será cada día más bastardeado por voces y modismos extranjeros» ${ }^{65}$. Para monseñor Franceschi, Franco parecía inspirado por un sincero deseo de justicia social y estaba construyendo un puente entre las tradiciones españolas y la modernización ${ }^{66}$. Por su parte, el sacerdote Julio Meinvielle no tardó en incorporar al debate argentino las tesis de la guerra santa y expiatoria enunciadas por la jerarquía católica española ${ }^{67}$. Con todo, no faltaron ásperas polémicas, como la que suscitó el pensador católico francés Jacques Maritain en el Congreso Internacional de escritores de los PEN's Clubs celebrado en septiembre de 1936 en Buenos Aires con unas declaraciones contra los rebeldes que fueron ampliamente descalificadas por los nacionalistas católicos ${ }^{68}$.

Desde el primer momento, y como había sucedido con la Dictadura primorriverista en la década anterior, la España de Franco se convirtió en el gran modelo contrarrevolucionario de la Argentina nacionalista ${ }^{69}$, ya que muchos intelectuales de esa tendencia percibieron el Nuevo Estado franquista como una variante totalitaria específica, íntegramente católica, del Nuevo Orden mundial. La causa rebelde fue apoyada por el presidente de la Academia de Letras, Carlos Ibarguren, el director de la Biblioteca Nacional Gustavo Martínez Zubiría, Juan B. Terán y el crítico militar del diario La Nación, coronel Gómez, entre otros $^{70}$. Como aseveraba líricamente Federico Ibarguren, «los campos de España dan testimonio de Dios en la sangre de sus mártires y de sus héroes. En comunidad de fe y confortados en su ejemplo, emprenderemos nuestra lucha» ${ }^{71}$.

Carlos Ibarguren, Pedro Obligado, Alfonso Laferrère, Rómulo Carbia, Leopoldo Marechal, Vicente Serra y Miguel Camino. También Cesar Pico, Manuel Gálvez, Gustavo Martínez Zuviría, Juan Carulla, Enrique Osses o Ramón Doll se adhirieron a la causa franquista. La Legión Cívica Argentina mandó un mensaje de adhesión a Franco que fue publicado en Revista Militar, octubre 1937 , p. 831-838. Sobre el movimiento de solidaridad con el bando franquista, vid. QUIJADA: Relaciones hispano-argentinas, 1936-1946, pp. 223-247. Un testimonio personal, en PÉREZ ORTIZ, Bernabé: Por España, Buenos Aires, s.ed., 1941.

65 Cit. por Quijada: Manuel Gálvez, p. 88.

${ }^{66}$ Criterio, 17-VII-1937.

${ }^{67}$ Meinvielle, Julio: Qué saldrá de la España que sangra, Buenos Aires, Secretariado de Publicaciones de la Asociación de los Jóvenes de la Acción Católica, 1937.

68 Véanse Halperín Donghi: La Argentina y la tormenta del mundo, pp. 98 ss.; TRIFone y SvARZMAN: La repercusión de la guerra civil española en la Argentina, p. 53 y ZANATTA: Del Estado liberal a la nación católica, pp. 198-208.

${ }^{69}$ RocK: La Argentina autoritaria, p. 125.

70 GOLDAR: Los argentinos y la guerra civil española, pp. 198-199, hace una relación de destacados intelectuales argentinos que apoyaron la causa rebelde, y asegura que el joven Julio Cortázar actuó en una sección de socorro falangista.

71 IBARGUREN: Orígenes del nacionalismo argentino, p. 392. 
Fue un momento de extraordinario florecimiento del mensaje hispanista más cercano al imperialismo espiritual postulado por Maeztu. Héctor Llambías reivindicaba en Crisol la herencia hispánica del criollismo argentino, y advertía que «nosotros participamos del imperio español de Indias. No fuimos jamás una colectividad cautiva» ${ }^{72}$. Historiadores católicos como Rómulo D. Carbia magnificaban el aporte de España en la definición de la identidad argentina ${ }^{73}$, y Juan Carlos Goyeneche declaraba con rotundidad en los editoriales de Sol y Luna: "Afirmamos que somos con España y con la América española un solo imperio espiritual, una sola cultura y una sola progresión histórica. Porque no renegamos de España tenemos el derecho de llamarnos argentinos, y argentinos anti-renegados. La nuestra no es una 'hispanofilia', sino una 'hispanofiliación'» ${ }^{74}$. Ernesto Palacio afirmaba: «somos españoles: mejor dicho. somos la prolongación de España en el Río de la Plata, por la persistencia entre nosotros de los elementos diferenciales, constituyentes de cultura, que son la religión y el idioma». Pero matizaba que «tenemos una manera peculiar de ser españoles, que ha cambiado de nombre y se llama ser argentinos. Constituimos una rama autónoma y no inferior de la hispanidad, según la palabra reanimada por Ramiro de Maeztu. Y donde se realizará mejor el destino de la raza, si aquí o allá, sólo el futuro puede decirlo» ${ }^{75}$. Por su parte, el senador nacionalista Matías Sánchez Sorondo, que viajó a la España nacionalista en marzo de 1937, previa visita a Mussolini, y se entrevistó con Franco, Antonio Tovar, Dionisio Ridruejo, Eugenio Montes y Eugenio Vegas Latapié, apoyaba el encuentro de Hispanoamérica con España en la aventura común imperial ${ }^{76}$.

La mayor receptividad de los sectores ultranacionalistas de la sociedad argentina a estos mensajes unificadores facilitó la labor de proselitismo y propaganda de los agentes intelectuales del bando franquista. Por ejemplo, Leopoldo Calvo Sotelo, José María Pemán, Eduardo Marquina o Fernando Díaz de Mendoza (sin contar al general José Millán Astray, que participó en varios actos del Club Español de Rosario a mediados de 1937) acudieron a Buenos Aires durante la guerra. Un caso relevante fue el del filósofo Manuel García Morente, un antiguo orteguiano converso al nacionalcatolicismo hispanista, empeñado en armonizar las dos grandes corrientes del nacionalismo autoritario español: la tradicionalista católico-monárquica heredera del pensamiento menendezpelayista y la emergente del fascismo español, heredero de la reacción de 1898. García Morente comenzó el 10 de julio de 1937 una visita a Argentina, y du-

72 Llambías, Héctor: «España y nosotros», en Crisol (Buenos Aires), 1-II-1938, p. 16.

73 CARBIA, Rómulo D.: Historia de la leyenda negra hispano-americana, Buenos Aires, s.ed., 1937.

${ }^{74}$ Editorial de Sol y Luna (Buenos Aires), no 3, octubre 1939, p. 1, cit. en GoYENECHE, Juan Carlos: Ensayos, artículos, discursos, Buenos Aires, Dictio, 1936, p. 145.

75 Palacio, Ernesto: «Los orígenes y el destino», en La historia falsificada, Buenos Aires, Difusión, 1939, pp. 62-63.

76 SÁNCHEZ SORONDO, Marcelo: «Dialéctica del Imperio», en Sol y Luna (Buenos Aires), ${ }^{\circ} 1$, 1938, p. 116. 
rante los años 1937-38 dictó cursos en Tucumán y Buenos Aires que dieron lugar a su obra Lecciones preliminares de filosofía (Buenos Aires, Losada, 1938). En sendas conferencias («España como estilo» y «El caballero cristiano») pronunciadas los días 1 y 2 de junio de 1938 en la Asociación de Amigos del Arte de Buenos Aires, recalcó el carácter espiritual de la Hispanidad, mezclando la tradición barresiana con la noción de «estilo» falangista: «La sangre, la raza, el habla materna, la tierra que nos vio nacer, está en la nación [...] Pero nada de eso es la nación [...] Nación es unidad de estilo en vida colectiva [...] La nación española es pues la hispanidad; es decir, no una 'cosa', sino la manera de ser de las cosas españolas» ${ }^{77}$. Atacaba las ideas románticas sobre la nación, y descartaba a partes iguales tanto el acto de adhesión a un pasado que sancionaba el plebiscito continuo según las ideas de Renan, como el respeto a un proyecto futuro de convivencia total de factura orteguiana. La actitud nacional no era sino la huella que sobre nuestro hacer real deja siempre el propósito ideal ${ }^{78}$.

Resultado directo de esas experiencias fue su obra Idea de la Hispanidad, donde puso de manifiesto el carácter místico y providencial de su concepción de la historia y su formación filosófica en el idealismo kantiano. García Morente identificaba el «ser nacional» con ese estilo de vida colectivo que personificó en el «caballero cristiano» de las Cruzadas, caracterizado por el espíritu misional, la grandeza, el arrojo, el estoicismo, el culto al honor y la religiosidad. La difusión de los «verdaderos principios religiosos» constituían en su opinión un elemento esencial de la misión histórica de la nacionalidad española, de suerte que aseguraba que el español no podía serlo sin ser católico ${ }^{79}$. La Hispanidad no era ya el resultado de una comunidad de lengua, de tradiciones o de historia, tal como la entendieron los epígonos del 98, sino «aquello por lo cual lo español es español» ${ }^{80}$. De este modo, García Morente propuso una trayectoria doctrinal inversa a la sugerida por Maeztu: la Hispanidad ya no era la expresión espiritual del destino histórico de España, sino un concepto apriorístico generador de esa misma personalidad nacional española («nación como estilo») y de la de las repúblicas latinoamericanas que asimilaron estos principios. En definitiva, España no ya no era la forjadora de la Hispanidad, sino que la ésta era un proceso causal del que España no era sino su producto. Con ello, las pretensiones de

77 García Morente, Manuel: Idea de la Hispanidad, Buenos Aires, Espasa-Calpe, 1939, pp. 48-49. Otras eds., en Madrid, Espasa-Calpe 1941 y 1961.

78 Ibid. p. 51.

79 García Morente, Manuel: Ser y vida del caballero cristiano, Madrid, Ed. Juventud de Acción Católica, 1945, p. 35. Esta imagen de «caballero cristiano» como símbolo de la aportación española al integrismo y el tradicionalismo católicos es obra de J. Bareille, prologuista de los Mélanges réligieux, philisophiques et littéraires de Jaime Balmes, París, Louis Vivès, 1854, vol. I, p. XVI. Cfr. HERMET, Guy: Los católicos en la España franquista, I. Los actores del juego político, Madrid, CIS, 1985, p. 88 nota 15 .

80 García Morente, Manuel: Ideas para una filosofía de la historia de España, Madrid, Universidad de Madrid, 1943, pp. 37, 47, 67 y 104. 
acción cultural española quedan plenamente justificadas, puesto que no suponían una actitud ajena a la propia esencia de Latinoamérica, sino que esta zona del mundo se definía precisamente por los valores esencialistas de la Hispanidad.

A partir de la obra sincrética de García Morente quedaban perfilados los dos proyectos nacionalistas que rivalizarían en el primer franquismo, y trataron de difundirse por América Latina. Por un lado, el nacionalismo católico y contrarrevolucionario de Acción Española, inspirado en el pensamiento reaccionario español y en Menéndez Pelayo. Por otro, el nacionalismo palingenésico, secular y revolucionario de Falange, inspirado en el 98 y en Ortega, opuesto a la concepción nacionalista romántica de la nación, que se proponía la superación del particularismo mediante el logro de la «unidad desde lo universal», y que por esas mismas razones hacía una apuesta explícita por el imperialismo ${ }^{81}$. Sin embargo, a pesar de que Pike calificara a la Hispanidad de concepto «más intransigente y teológicamente más dogmático, más militantemente católico» que el de Hispanismo ${ }^{82}$, sus ideas anejas (patria, nación, estado, raza, imperio o catolicismo) fueron especialmente adaptables a la realidad política española del momento y a cada peculiar circunstancia exterior, influyendo en la creación de una imagen polisémica y de unas formas simbólicas sobre América (clichés, estereotipos, xenotipos, opiniones, prejuicios) que podían avalar las intenciones «regeneradoras» y de retorno a la unidad política y cultural en el seno del «Nuevo Estado», o bien propiciar eventualmente una política exterior expansiva, como postulaba el sector más totalitario de Falange.

\section{LAS LIMITACIONES DEL PROYECTO HISPANISTA DEL FRANQUISMO}

El aplastamiento bélico de los nacionalismos alternativos liberal-democráticos y periféricos presentes en el proyecto republicano no significó su desaparición del debate político en Argentina, donde se mantuvo vivo gracias a su proyección en ámbitos de sociabilidad regional de la emigración y a la llegada al país de intelectuales exiliados de la talla de Ricardo Baeza, Luis Jiménez de Asúa, Claudio Sánchez Albornoz, Francisco Ayala, Lorenzo Luzuriaga, Rafael Alberti o Arturo Serrano Plaja ${ }^{83}$. A las dificultades del Nuevo Estado franquista para lograr la adhesión incondicional de la colonia española en Argentina se sumaron otros obstáculos de origen metropolitano, doméstico e internacional.

La llegada el 31 de diciembre de 1936 de Juan Pablo de Lojendio como cabeza de la oficiosa «Representación del Gobierno Nacional de España en Bue-

81 SAZ CAMPOS, Ismael: España contra España. Los nacionalismos franquistas, Madrid, Marcial Pons, 2003, pp. 148-149.

82 PIKE: Hispanismo, p. 299. En la p. 1 de esta obra, el autor define el Hispanismo como una «fe en la existencia de una familia hispánica, comunidad o raza» a través de la cultura, la historia, las tradiciones, etc.

83 ZuletA, Emilia de: España en la Argentina: el exilio literario de 1936, Buenos Aires, Atril, 1999. 
nos Aires» se dirigió en teoría a coordinar y unificar los esfuerzos de la colonia nacionalista, que sólo representaba un $25 \%$ del total de emigrados ${ }^{84}$. Lojendio había recibido instrucciones reservadas para «hacerse amigo de forma absolutamente privada de las principales autoridades federales, sobre todo aquéllas que simpatizan con nuestra sagrada causa y bajo cuerda, sin comprometerlos, se obtendría de ellas las medidas convenientes en favor nuestro. La propaganda de nuestra causa no debe ser hecha públicamente por nuestro representante, sino por oradores enviados al efecto desde la España Nacional». Con respecto a la colectividad española residente en Buenos Aires, Lojendio fue aleccionado para «atraerse a nuestra causa a los que allí han triunfado, es decir, a los de calidad y riqueza, pues los demás seguirán a éstos en la medida que nuestro Ejército va conquistando territorio, aún en poder de la tiranía roja» ${ }^{85}$. Sus principales interlocutores locales fueron los senadores Matías Sánchez Sorondo (ministro del Interior con Uriburu), Benjamín Villafañe y el Dr. Manuel Fresco, gobernador filofascista de la provincia de Buenos Aires entre 1936 y $1940^{86}$. En la colonia también prevaleció un modo de actuación proselitista centrada en los sectores de élite (religiosos, grandes empresarios o directores de centros benéficos y asistenciales), cuya actitud favorable al Nuevo Estado debería facilitar el camino a una ulterior penetración en el grueso de las comunidades de emigrantes ${ }^{87}$.

Esta discreción y voluntad selectiva en la acción propagandística iban unidas a una enérgica labor de coordinación y de control de las diversas entidades de apoyo a la causa rebelde. Las Juntas Nacionalistas Españolas, constituidas de forma más o menos espontánea a inicios de la guerra por los representantes de las diversas formaciones de derecha (Centro Acción Española, Agrupación Tradicionalista Española, Agrupación Monárquica Española, Falange Española y Acción Popular), fueron objeto de una creciente fiscalización, que adoptaría forma oficial tras el decreto de Unificación política de abril de 1937. El intento de Lojendio de forzar la centralización de ayudas en una sola entidad, unificando en junio todas las colectas en una Suscripción Nacionalista Española gestionada por hombres de su entera confianza, fue entendida como el primer paso para una absorción política forzada, y provocó, por ejemplo, la escisión del carlismo en una tendencia intransigente capitaneada por Francisco de Paula Oller (representante carlista en el continente desde $1898^{88}$ ) y otra de tendencia «juanista». Dentro de estos esfuerzos centralizadores de Lojendio se enmarcó también

84 PÉRez OrTiz: Por España, p. 158.

85 «Instrucciones reservadas», 29-IX-1938, en AMAE, leg. R-1002, exp. no 14.

86 FALCOFF: «Argentina», p. 320.

87 GonZÁlez CALlejA, Eduardo: «¿Populismo o captación de élites?: luces y sombras en la estrategia del Servicio Exterior de Falange Española», en ÁlvarEZ JuNCO, José y GONZÁLEZ LEANDRI, Ricardo (comps.): El populismo en España y América, Madrid, Ed. Catriel, 1994, p. 85.

88 Sobre Francisco de Paula Oller, presidente del Círculo Tradicionalista de Buenos Aires desde fines de siglo y fundador del periódico El Legitimista Español, véase BIAGINI: Intelectuales y políticos españoles a comienzos de la inmigración masiva, p. 25. 
el lanzamiento en septiembre de 1937 del boletín Orientación Española, que contó con corresponsales en toda América Latina y se mantuvo activo hasta 1944.

La evolución de Falange resulta ilustrativa de las limitaciones que tuvo que afrontar el nacionalismo totalitario español para desplegar su campaña proselitista de forma autónoma. Fundada a inicios de la guerra por Nicolás Quintana bajo la tutela de la Casa de España, desarrolló una intensa labor propagandística y asistencial ${ }^{89}$, pero no logró obtener el monopolio de la acción nacionalista en la república. La llegada en julio de 1937 de una misión representativa de FET de Marruecos (Augusto Atalaya, Juan Antonio Martín Cotano, Rafael Duyos, Joaquín Martínez Arboleya y Antonio Solano) provocó un relevo general de mandos: el jefe falangista en Buenos Aires, Nicolás Quintana, fue expulsado y sustituido a fines de 1937 por Martín Cotano, jefe de Prensa y Propaganda ${ }^{90}$. El nombramiento del poeta Rafael Duyos Giorgeta como jefe local de la capital porteña el 21 de julio de 1937 y como jefe regional el 7 de marzo de 1938, mientras el conde de Montarco era nombrado en agosto inspector de FET en Argentina ${ }^{91}$, tendió a una suavización de los enfrentamientos entre los grupos nacionalistas españoles de origen monárquico menos dispuestos a acatar las directrices de Falange, pero los planes de ésta para controlar la colonia a medio plazo no variaron ${ }^{92}$.

Un año después de la Unificación, Lojendio censuraba «la torpeza de los jefes de Falange encargados de realizarla, la ha impedido constantemente», en alusión evidente a Eugenio Montes (jefe de una misión falangista compuesta por el jesuita Francisco Peiró, el director del Archivo de la Corona de Aragón Fernando Valls Taberner, el representante de la Delegación Nacional de Prensa y Propaganda de FET Gonzalo Valentí Nieto y José Ibáñez Martín, que desde el 2 de octubre de 1937 recorrió por un año Uruguay, Argentina, Chile, Perú, Panamá y Cuba), a Augusto Atalaya y al antiguo jefe provincial Nicolás Quintana ${ }^{93}$. Entre las trabas que impedían una actuación unificada en la República Argentina, los diplomáticos de Burgos señalaban «de una parte la concepción del programa de Falange interpretado por unos como movimiento de ideas sociales avanzadas y de reivindicaciones exageradas encubiertas en una

89 Delgado, GonzÁlez Calleja y GonzÁlez de Oleaga: «La dinámica franquismo/oposición en Argentina», pp. 277-278, notas 4 y 5. Al parecer, el primer acto público falangista fue el homenaje a José Antonio Primo de Rivera celebrado en Buenos Aires el 21-XI-1936.

${ }_{90}$ Notificación del jefe del Servicio Exterior de Falange a Lojendio, Salamanca, 14-VIII-1937, en AMAE, leg. R-1009, exp. n ${ }^{\circ} 2$

${ }^{91}$ Carta del Delegado Nacional del Servicio Exterior a Rafael Duyos, Salamanca, 4-IX-1938, en Archivo General de la Adminsitración, Alcalá de Henares (en adelante, AGA), Presidencia, Secretaría General del Movimiento, Servicio Exterior, leg. 59.

92 DuYOS, Rafael: «Tarea de las Falanges en América. Corrigiendo entusiasmos», en AGA, Presidencia, Secretaría General del Movimiento, Servicio Exterior, leg. 15.

93 Informe de Juan Pablo de Lojendio a Jordana sobre los problemas en Argentina, 12-IV1938, en AMAE, leg. R-1009, exp. nº 2. 
aparente disciplina y sumisión a las autoridades legalmente constituidas. De otra, el espíritu particularista de las colonias, divididas en grupos, atentos muchas veces sus dirigentes más que a volcarse de asuntos de interés patriótico en labrarse una situación preponderante entre sus compatriotas»94. Aunque Lojendio llegó a amenazar con una purga interna para dar a la Falange argentina un mayor sentido de la jerarquía y la disciplina, el reconocimiento por el gobierno de Roberto M. Ortiz el 26 de febrero de 1939 y el final casi inmediato de la guerra civil dulcificaron parte de estas rivalidades internas.

Tras la contienda, FET cobró una influencia creciente entre los miembros de la colonia española simpatizantes del régimen franquista. Entre 1939 y 1942, la singularización de la colonia como «blanco» de las estrategias diplomáticas obedeció a la necesidad de contar con portavoces en el continente que difundiesen la «verdad nacional-sindicalista». La elección que se hizo del campo de actuación fue particularmente selectiva y exclusivista, criterio que contrastaría con el utilizado a partir de $1943^{95}$. Falange mantenía cordiales relaciones con las formaciones nacionalistas o de extrema derecha nacionales y extranjeras que actuaban en el país ${ }^{96}$. Aunque la vieja derecha liberal latinoamericana había mostrado una clara proclividad hacia los nacionalistas durante la guerra, fue la «nueva derecha» inspirada en los modelos corporativistas y fascistas europeos la fracción verdaderamente incondicional del Nuevo Estado franquista y de su partido único ${ }^{97}$. Los autores de referencia de esta corriente veían en el nacionalismo franquista una opción fascista católica que podía dar la réplica tanto al liberalismo en crisis como al indigenismo y sus embates populistas de esos años ${ }^{98}$. De ese modo, Federico Ibarguren podía opinar que el pensamiento de José Antonio Primo de Rivera era «totalmente cristiano [...] libre de las fantasías racistas de Hitler y de Rosenberg ${ }^{99}$.

${ }^{4}$ Informe de M. Pujadas, jefe de la Sección Política Ultramar y Asia, a Jordana, 5-III-1938, en AMAE, leg. R-1009, exp. no 2

95 GonZÁleZ DE OlEAGA, Marisa: Las relaciones hispano-argentinas, 1939-1946. Identidad, ideología y crisis, Madrid, Ed. de la Universidad Complutense, 1991, p. 76 (reed. con el título El doble juego de la Hispanidad. España y la Argentina durante la Segunda Guerra Mundial, Madrid, UNED, 2001, p. 54).

${ }_{96}$ Entre otras, el Partido Fascista Argentino, el Movimiento Restauración, la Defensa Social Argentina, la Alianza de la Juventud Nacionalista (desde 1941, Alianza Libertadora Nacionalista, grupo properonista), la Asociación Nacionalista de Estudiantes Secundarios afín a la Legión Cívica, la Unión Cívica Nacionalista, la Alianza Nacionalista Argentina, la Légion Nationale Belge y las secciones locales del PNF y el NSDAP. Según BUCHRUCKER: Nacionalismo y peronismo, p. 232, «después de la victoria de Franco en España podía fácilmente conjeturarse que el lema hispanista podía ser manipulado con el fin de lograr la fundación de una 'Internacional' iberoamericana, integrada por organizaciones antidemocráticas de extrema derecha que aspiraban a establecer regímenes de corte falangista en sus respectivos países».

97 PARDO: iCon Franco hacia el Imperio!, p. 60.

98 Ibid., p. 62.

99 IBARGUREN: Orígenes del nacionalismo argentino, p. 364. 
Ciertamente, el fascismo español se había visto desde un primer momento ampliamente influido por las formulaciones ideológicas de Maeztu, pero también bebió de fuentes propias. Las consideraciones sobre la decadencia y la resurrección de la identidad nacional mediante una aspiración ecuménica de corte romano imperial expuestas por el protofascista Ernesto Giménez Caballero en obras como Genio de España (Madrid, La Gaceta Literaria, 1932) o La Nueva Catolicidad (Madrid, La Gaceta Literaria, 1933100) jugaron un nada desdeñable papel en los llamamientos imperialistas de las JONS o de la posterior Falange Española. Esa aspiración al imperio como culminación inevitable de una ideología ultranacionalista proyectada a valores y principios universales ${ }^{101}$ era compatible con la doctrina maeztiana de la Hispanidad como realización plena de un fin humano supranacional. Ya hemos visto que esta era la intencionalidad de la obra sincrética de García Morente. Bien es cierto que las ideas de imperio, Hispanidad, raza o cultura fueron reformuladas por los teóricos de los grupos fascistas españoles en un sentido más explícito y beligerante.

Según Buchrucker, «las concepciones falangistas acerca de la Hispanidad reinterpretaban en términos de poder una constelación de realidades culturales. Para todos los pueblos de raíz hispánica había allí una idea movilizadora que prometía vagamente un papel decisivo en la política mundial. En el francofalangismo y el nacionalismo restaurador esta idea cumplía una función similar a la del 'Impero' en la visión geopolítica del fascismo italiano» ${ }^{102}$. En el primer lustro posterior a la Unificación, Falange no asumió plenamente la idea católico-ecuménica subyacente en el hispanismo reaccionario español. Los representantes de la intelligentsia falangista más radical buscaron y encontraron otro objetivo movilizador adecuado para la deseada proyección de las energías nacionales hacia el exterior: la noción orteguiana del imperio, sin especiales connotaciones éticas, morales o religiosas, puro instrumento de reafirmación de las potencialidades vitales de la nación en legítima concurrencia territorial o espiritual con el Geist de los otros pueblos. De hecho, la idea de imperio en el fascismo español tuvo tres connotaciones básicas: una valoración como afirmación y aglutinante nacional (unidad y reconstrucción interna) procedente de Ortega; un contenido espiritual-cultural inspirado en Maeztu y en el pensamiento católico-tradicionalista, susceptible de ser «exportado» con reparos hacia minorías afines en Latinoamérica, y un componente estrictamente fascista de franca expansión territorial y de contenido fuertemente populista (las teorías de expansión de un régimen nacional-revolucionario de masas desarrolladas por Giménez Caballero o Ramiro Ledesma), que fue desplegado de forma más episódica. Estos tres objetivos se mezclaron o se sucedieron en la acción exterior de Falange: como imagen simbólica que fomentara la unidad y el consenso interiores, como

100 Véase también su obra Amor a Argentina o El genio de España en América, Madrid, Editora Nacional, 1948.

101 SAZ: España contra España, pp. 267-308.

102 BuCHRUCKER: Nacionalismo y peronismo, p. 180. 
instrumento de acción cultural con pretensiones de influencia política, y como justificación de las propias aspiraciones de expansión o de colaboración con el imperialismo nazifascista durante la fase inicial de la Segunda Guerra Mundial.

El régimen de Franco no consiguió dotarse de un vehículo eficaz y unívoco de difusión de esa doctrina hispanista de tono cada vez más beligerante. A las deficiencias estructurales de la organización falangista se unió un movimiento de reacción protagonizado por buena parte de la opinión pública argentina contra la intromisión de las filiales de ciertos partidos totalitarios extranjeros en los asuntos internos del país (cuyo más famoso ejemplo fue la denuncia del «complot nazi» en la Patagonia ${ }^{103}$ ), y que culminó en la emisión el 15 de mayo por el presidente Ortiz de un decreto que obligaba a todas las asociaciones con o sin personería jurídica a comunicar en un plazo de noventa días al Ministerio del Interior y a los Jefes de Policía sus domicilios sociales, denominación, finalidades, reglamentos, estatutos, nómina completa de componentes y libro de actas (art. 1). Se prohibía la utilización de distintivos o banderas extranjeras (art. 2), la intromisión en los asuntos internos argentinos y el proselitismo bajo promesa de ventajas o amenazas a un ideario político (art. 3). Las medidas que definitivamente vedaban a FET toda posibilidad de actuación pública quedaban expuestas en el artículo 5: toda organización debería tener origen en Argentina, sin depender de entidades exteriores. Además, sus autoridades y reglamentos deberían tener origen nacional y habrían de sujetarse a los principios democráticos, so pena de disolución fulminante de la entidad y procesamiento de sus promotores (art. 8) ${ }^{104}$. Esta medida coincidió con una campaña en pro de la unidad de la colonia española alrededor del nuevo régimen, en la que una vez más se rumoreó la conjunción forzosa de todas las entidades españolas en Argentina ${ }^{105}$.

Acosada por el gabinete Ortiz, hostilizada por buena parte de la opinión pública autóctona y por la importante colonia española republicana, Falange suspendió sus actividades en agosto de 1939, tras agotar el plazo otorgado por el gobierno ${ }^{106}$. El 13 de noviembre de 1940 se decretó su disolución oficial y el traspaso de sus actividades a la entidad cultural-asistencial Hermandad Hispano-Argentina ${ }^{107}$, y posteriormente al Hogar Español. Sólo la Casa de España creada en mayo de 1940 y la prestigiosa Institución Cultural Española mantuvieron la convocatoria de actos públicos estrictamente culturales.

103 «Del informe del Fiscal Federal sobre la investigación de actividades contra la soberanía argentina», en El Diario Español (Buenos Aires), 6-V-1939, p. 3. Sobre el proceso posterior a miembros del NSDAP en Argentina, vid. ibid., 17-XI-1939, p. 4.

104 «Ha reglamentado el gobierno argentino las actividades de las asociaciones extranjeras con personería jurídica», en El Diario Español (Buenos Aires), 16-V-1939, p. 3.

105 El Diario Español (Buenos Aires), 15-V-1939, p. 3 y 20-V-1939, p 4.

106 «Suspensión de F.E.T.», en El Correo de Galicia (Buenos Aires), 17-IX-1939, p. 3

107 El Proyecto de Estatutos de la Hermandad Hispano-Argentina, en AGA, Presidencia, Secretaría General del Movimiento, Servicio Exterior, leg. 59, carp. 43. 
El estallido de la guerra mundial fue el acontecimiento clave de ese cambio de signo del discurso nacionalista en España y Argentina. No sólo se perdió gran parte del ascendiente trabajosamente logrado sobre la colonia (cuyo sector más acomodado tenía inequívocos vínculos materiales con los aliados), sino la benevolencia del propio gobierno argentino. Lojendio abandonó el país en noviembre de 1939, siendo sustituido de forma interina por el cónsul general Francisco Amat, y éste en octubre de 1940 por el marqués de Magaz. Fue entonces cuando se fueron perfilando con nitidez dos proyectos concurrentes de política exterior: el puramente conservador patrocinado por el conde de Jordana, partidario de mantener la neutralidad formal proclamada en 1938 y normalizar relaciones con América Latina, y el fascista e imperialista preconizado por Ramón Serrano Suñer, cuya llegada al Ministerio de Exteriores en octubre de 1940 fue el momento culminante del ascenso de la corriente totalitaria, empeñada en dar un carácter más combativo a la actuación diplomática ${ }^{108}$. Esa apuesta no estaba exenta de riesgos: en abril de 1941, Magaz advertía a Serrano que «el parangón entre el espacio vital, que envuelve la idea de dominio, y el espacio espiritual, lo mismo que mezclar en ese parangón a Hispanoamérica con África, suena muy mal en los oídos argentinos. Estamos en un período sumamente delicado para hacer una obra seria y provechosa de acercamiento espiritual. Una torpeza de nuestra política de captación puede comprometer y aun destruir lo que aquí existe de Hispanidad»109.

El impulso dado a la creación de instituciones y organizaciones dedicadas específicamente a la actuación político-cultural en América fue un buen exponente de ese hispanismo beligerante patrocinado por el falangismo más radical. La Asociación Cultural Hispanoamericana fue creada a inicios de 1940 a impulso del Ministerio de Asuntos Exteriores con el objeto de potenciar las relaciones culturales entre España y América Latina ${ }^{110}$. La Junta de Relaciones Culturales establecida en el Ministerio de Exteriores del 23 de abril de 1938 dejó paso en marzo de 1940 a una Sección de Relaciones Culturales, y ésta fue sustituida a su vez el 10 de octubre de ese año por el Consejo de la Hispanidad, reducto de la élite falangista encargada de mantener la utopía política imperialista hacia Latinoamérica en los primeros años del franquismo.

En septiembre de 1941, el canciller del Consejo de la Hispanidad, Manuel Halcón, postulaba una inteligencia con los fraccionados grupos nacionalistas argentinos "simpatizantes con los nuevos sistemas políticos europeos», ya que «España, si ha de pensar en influir en Ultramar, será siempre a través de algunos de los partidos políticos que operan en cada uno de los países iberoamericanos. Las relaciones puramente diplomáticas, de Gobierno a Gobierno, suelen

108 PARDO: iCon Franco hacia el Imperio!, pp. 24-25.

109 Magaz a Serrano, 17-IV-1941, en AMAE, leg. R-1910, exp. no 3.

110 Su presidente fue el ex-embajador argentino en España Daniel García Mansilla. Sobre esta asociación, vid. Delgado Gómez-EsCalonilla, Lorenzo: Imperio de papel. Acción cultural y política exterior durante el primer franquismo, Madrid, CSIC, 1992, pp. 248-254. 
tener repercusiones débiles y lentas, y la agrupación de los españoles allí residentes en Falange, sirve más bien a la provocación que a la trascendencia de nuestra política. Por eso resulta del máximo interés contar con la existencia de movimiento nacionalista argentino de referencia, dada su proximidad a la idea totalitaria y corporativa» ${ }^{111}$. En su respuesta, el embajador Magaz consideraba esto muy arriesgado, ya que los grupos nacionalistas, «salvo raras excepciones, todos defienden como principios fundamentales el sostenimiento de la Religión Católica y su afinidad con al España actual; pero es un movimiento que empieza y que en su totalidad agrupa a un número bastante reducido de afiliados, aunque por pertenecer casi todos ellos a la juventud salida de las aulas ofrezca un porvenir más halagüeño» ${ }^{112}$. Advertía además que unas muestras demasiado ostensibles de amistad hacia esa corriente intelectual podían ser interpretadas como un injerencia en la política interior, y perjudicar la acción exterior española en su conjunto.

A pesar de estas admoniciones, desde mediados de 1941 a inicios de 1942 el Consejo de la Hispanidad trató de invitar a una serie de figuras de la intelectualidad ultraconservadora latinoamericana (entre ellos los argentinos Ignacio Anzoátegui, Cesar E. Pico, Leopoldo Marechal, Juan Carlos Goyeneche, José María Estrada, Marcelo Sánchez Sorondo y Alfredo Torruella), que debían reunirse en Madrid en la primera quincena de octubre de 1941 con el fin de «estudiar los puntos fundamentales sobre los que ha de basarse la forma de presentar al Mundo la doctrina de la Hispanidad, establecer las normas par su desarrollo y redactar las consignas que han de animarla» ${ }^{113}$, pero las presiones diplomáticas de los países anglosajones frustraron el proyecto. Con la entrada de Estados Unidos en la guerra a fines de 1941 la propaganda antifalangista se intensificó, aunque el régimen español pudo contar con la protección del canciller argentino Enrique Ruiz Guiñazú, que influyó para que el gabinete Castillo archivase definitivamente el informe de la Comisión Investigadora sobre Actividades Antiargentinas constituida el 19 de junio de ese año.

111 AMAE, leg. R-1080, exp. no 25.

112 Magaz a Serrano, 20-IX-1941, en AMAE, leg. R-995, exp. nº 28. Los grupos políticos que reseñaba eran: Restauración, Alianza Libertadora Nacionalista (el grupo nacionalista más importante de los años 40, creado en la década anterior por personas vinculadas a la Legión Cívica Argentina y que a inicios de la década decía tener 11.000 miembros liderados por el general Juan B. Molina, incorporado entonces a la Wehrmacht), Liga Republicana, Legión de Mayo y Fuerza de Orientación Radical de la Joven Argentina (FORJA). Los grupos intelectuales eran, de mayor a menor hispanismo, Sol y Luna ("publicación netamente hispanófila, que mantiene asidua correspondencia con los intelectuales españoles, de cuyos ideales recibe inspiración»), Nueva Política («la publicación de mejor calidad dentro del nacionalismo») y Restauración. En un segundo nivel estarían Crisol («diario hispanófilo, católico y nacionalista»), El Pampero (con ciertas disidencias internas), El Fortín, Liga Republicana, Alianza de la Juventud Nacionalista y Legión de Mayo.

113 AMAE, leg. R-2461, exp. $n^{\circ}$ 83. Otros argentinos que viajaron a España en esa época bajo el manto del Consejo de la Hispanidad fueron Carlos del Real Asúa y Manuel Vega (DelGado GómeZ-Escalonilla, Lorenzo: Diplomacia franquista y política cultural hacia Iberoamérica, 19391953, Madrid, CSIC, 1988, p. 70 nota 69). 
Como hemos señalado, entre los grupos intelectuales valedores del hispanismo franquista destacó la revista Sol y Luna, dirigida por Juan Carlos Goyeneche, quien viajó a Madrid en abril de 1942, contactando con Serrano Suñer, Jorge Vigón y Franco ${ }^{114}$. En sus páginas matizó el escritor monárquico José María Pemán que «la hispanidad en toda su anchura es la que puede dar la forma del único totalitarismo legítimo, o sea, el totalitarismo cristiano, donde verdaderamente se salva todo: la Nación y el Estado, de una parte, y de otro la dignidad de la persona humana, el Espíritu, la cultura: todo lo que está en peligro en Europa». La misión del mundo cristiano sintetizado en la Hispanidad era la conversión del nazismo al cristianismo, es decir: «absorber esa fuerza pagana, llevarla a la síntesis con la verdad cristiana: bautizar otra vez el Imperio y coronar otra vez con manos papales a Carlomagno», es decir, a Hitler ${ }^{115}$. En ese mismo sentido, César E. Pico declaró en Sol y Luna que la labor de los católicos debía dirigirse a cooperar con el fascismo para facilitarle el hallazgo de una doctrina católica que le alejase de los «ideales paganos» ${ }^{116}$. Para G. Riesco, la hispanidad era, pura y simplemente «la modalidad de nuestro ser [...] catolicidad e hispanidad son el gran vivero de la argentinidad [...] todo lo que no arranque del sentimiento hispánico y del concepto católico es atentatorio a nuestro ser» ${ }^{117}$. Pero la polémica sobre los límites del totalitarismo asumible por el régimen, alimentada por monárquicos y falangistas, sufrió los embates de las sucesivas crisis políticas de mayo de 1941 y agosto de 1942.

A partir de otoño de 1941 se pudo constatar el retorno a un estilo menos beligerante, en el que la Hispanidad adoptaba los contornos de un fomento de la vinculación espiritual y cultural con América. Los sucesos de Begoña abrieron un proceso más intenso de «recatolización» de la Falange ${ }^{118}$. El viraje de la política exterior española en la segunda mitad de 1942 se tradujo en el propósito de despojar de todo contenido político las actividades oficiales en el continente americano, ya que la imagen de FET como «Ejército secreto del Eje», ponía en peligro los fundamentos mismos de la influencia española en América. El retorno de Jordana a la cartera de Exteriores en septiembre (que coincidió con la celebración el 16 de septiembre de 1942 del Primer Congreso de Cultura Hispanoamericana patrocinado por el arzobispo de Salta monseñor Talavella con el auspicio del presidente Castillo, donde se difundió una declaración re-

114 BUCHRUCKER: Nacionalismo y peronismo, p. 183. En abril de 1942, Magaz tuvo ocasión de hablar con los elementos nacionalistas más destacados gracias a la invitación que se le cursó para asistir a la comida de despedida ofrecida a Goyeneche, quien cursó estudios en Madrid entre 1943 y 1946.

115 Pemán y Pemartín, José María: «Pasemos a la escucha», en Sol y Luna, no 4, mayo 1940 , p. 90. En ese mismo número el editorial de la revista proclamaba alborozado que «la Hispanidad se atreve a gritar ahora el advenimiento de su segunda primavera».

116 Pico, César E.: «Totalitarismo», en Sol y Luna, no 3, octubre 1939, pp. 59-80.

117 RiesCO, G.: «El eje diamantino de nuestro ser», en El Pueblo, 12-X-1941.

118 Sobre la apropiación del tradicionalismo católico (sobre todo el historicismo de Menéndez Pelayo) por Falange, vid. SAZ: España contra España, pp. 212 ss. 
afirmadora del nacionalismo y la neutralidad argentina) supuso una notable reducción de la fraseología imperialista.

Con el cambio de signo de la Guerra Mundial y el repliegue diplomático español aumentaron las suspicacias con respecto a la sinceridad y utilidad de las relaciones con los nacionalistas argentinos. Magaz creía que su hispanofilia no obedecía a un sincero amor por España, sino al deseo de oponer un bloque de habla española a la hegemonía norteamericana: "Los españolistas de aquí — señalaba el embajador - ensalzan a la España del descubrimiento, de la conquista, del siglo de oro de nuestra literatura y del renacimiento en el arte, pero miran con desconfianza a la España totalitaria de hoy a la que creen supeditada a la influencia nazi» ${ }^{19}$. A pesar de todo, en esos mismos días se firmó un acuerdo comercial que supuso un significativo aumento de los volúmenes de intercambio, y poco después fue rubricado un convenio sobre relaciones culturales que se interpretó como un reforzamiento de los vínculos hispanistas que los nacionalistas sustentaban en Argentina ${ }^{120}$.

En general, el hispanismo argentino acogió la fraseología imperialista de Falange con mal disimulada prevención. La hispanidad no fue un concepto unívoco, ya que unos lo identificaron con el régimen de Franco y otros, como monseñor Gustavo Franceschi, como un punto de referencia meramente espiritual y cultural en su afán de restauración cristiana ${ }^{121}$. Para Franceschi, que había visitado la España franquista en abril-junio de $1937^{122}$, la Hispanidad no era sinónimo de catolicidad, sino una determinada civilización fundada en valores intangibles que le servía de vehículo de difusión, y que en Argentina podía ayudar resolver el problema de la identidad nacional ${ }^{123}$. Esta visión instrumental le separaba evidentemente del esencialismo hispanista de un Maeztu. Por su parte, Gálvez afirmaba que «exaltar a España, gritar por España no precisamente la del general Franco, sino la España eterna, es realizar obra útil y patriótica» ${ }^{124}$. Desde Sol y Luna, revista que a fines de 1942 celebraba la derrota de la «mala Europa» frente a los nazis dedicando un número monográfico a exaltar la época colonial hispana en contraposición a la colonización materialis-

119 Magaz a Jordana, 30-IX-1942, en AMAE, leg. R-1371, exp. nº 3.

120 BuCHruCKer: Nacionalismo y peronismo, p. 226; Figallo, Beatriz J.: El Protocolo Perón-Franco. Relaciones hispano-argentinas, 1942-52, Buenos Aires, El Corregidor, 1992, pp. 20-28 y GONZÁLEZ DE OlEAGA: Las relaciones hispano-argentinas, 1939-1946, pp. 247-251 (El doble juego de la Hispanidad, pp. 151-154). Vid. también el libro del embajador español en Argentina CAMPANO, José: Perón y España. Politica social, interna e internacional, Buenos Aires, Ed. Plus Ultra, 1983, pp. 61-70.

121 ZanatTA: Del Estado liberal a la nación católica, p. 292.

122 Sobre sus impresiones, recopiladas en En el humo del incendio, Buenos Aires, Difusión, 1988, vid. TRIFONE y SvARZMAN: La repercusión de la guerra civil española en la Argentina, pp. 58-59.

${ }^{123}$ FranCESCHI, Gustavo J.: «Hispanidad», en Criterio, 23-X-1941. Más tarde, Franceschi comenzó a criticar tímidamente la deriva totalitaria del franquismo. Vid. «Latinismo, hispanismo, cristianismo», en Criterio, 9-VII-1942.

124 GÁlveZ: España y algunos españoles, p. 5. 
ta inglesa, Cesar E. Pico reconocía la identidad esencial del carácter hispánico a uno y otro lado del Atlántico ...

«Somos, repito, europeos en América. Pero no europeos primariamente, sino europeos oriundos de aquellas naciones que aquí arraigaron [...] Somos españoles en América. Y somos españoles porque es nuestro modo — histórico y social— de ser europeos. La hispanidad aparece así como la sociedad supranacional en que conviven los individuos de Hispano-América. Es como una prolongación de España que nos permite participar de Europa a través de España [...] para nosotros es el trasfondo social de nuestra nacionalidad concreta [...] Sin la convivencia hispánica, nos reduciríamos a ser europeos sin Europa españoles sin España, es decir, un imposible»125.

... pero más adelante hace una severa crítica de la adaptación histórica de esos valores por la propia España franquista:

«No reconocemos la voz del espíritu en la fraseología retórica con que se nos llama a la hispanidad. En la hispanidad ya estamos, pero falta su actuación eficiente. Se nos recuerda el parentesco racial, la unidad de lengua, la comunión en una misma fe religiosa. Pero las sociedades históricas han podido formarse sin unidad de raza, de idioma y de religión, aunque reconozcamos en esa triple unida una corroboración formidable de los vínculos sociales Tenemos así, a disposición nuestra, magníficos instrumentos, pero está todavía dispersa la materia donde aplicarlos. Las Españas están invertebradas. La forma de la hispanidad es, por ahora, un magnífico proyecto de vida futura».

Pico acababa proponiendo la idea de una confederación capaz de «la adecuada actualización de nuestro destino común en la historia ecuménica» ${ }^{126}$. Por su parte, Julio Irazusta ensalzaba en 1942 el tradicionalismo nacional-católico representado en Menéndez Pelayo, omitiendo cuidadosamente toda alusión al proyecto nacional-imperialista concurrente de Falange:

«Pertenecemos a la mejor tradición intelectual del mundo, a la progenie de los definidores de dogmas, evangelizadores de infieles y unificadores del universo; y sin embargo vivimos postrados de admiración ante los destructores de esos bienes perdidos [...] La recordación en honor de Menéndez y Pelayo es uno de los

125 Pico, César E.: «Hacia la Hispanidad», en Sol y Luna, no 9, diciembre 1942, pp. 136-137, reproducido en Revista de Estudios Políticos (Madrid), n ${ }^{\circ} 18$, 1944, pp. 591-621. Publicado como folleto en Buenos Aires, 1943. Entre los artículos publicados en Sol y Luna, $\mathrm{n}^{\circ}$ 9, diciembre 1942, destacan los de CARBIA, Rómulo D.: «La Iglesia en la 'Leyenda Negra' hispanoamericana» (pp. 53-60); RAmos, Juan P.: «La cultura española y la conquista de América» (pp. 29-48); EsPEZEL, Alberto: «El Imperio Español» y MEDRANO, Samuel W.: «Educación y Cultura en la Argentina Colonial».

126 PICO, César E.: «Hacia la Hispanidad», en Sol y Luna, no 9, diciembre 1942, p. 141. Respuestas a este artículo: LISARRAGUE, Salvador: «Sentido de la Hispanidad», en Revista de Estudios Políticos (Madrid), no 9, 1943, pp. 167-173; EscobAR, José Ignacio: «La Hispanidad ante el actual momento histórico», en ibid., no 11, 1943, pp. 163-178 y SÁNCHEZ BELLA, Alfredo: «La vocación misional del mundo hispánico», en ibid., nº 11, 1943, pp. 179-186. 
pasos hacia la recuperación de los pueblos con nuestra comunidad espiritual, como la obra del maestro lo fue de la restauración intelectual de su patria»127.

Estas críticas más o menos explícitas al nacionalismo de cuño falangista obedecían en buena parte al ambiente de creciente hostilidad provocado por el cambio del signo de la guerra mundial. La actitud general de los gobiernos de la zona, presionados por la administración norteamericana y espoleados por una propaganda empeñada en identificar a Falange con nazismo, fascismo, imperialismo y aspiración neocolonial, fue desde fines de 1940 el entorpecimiento o la persecución de todo tipo de actividades fascistas, fundándose en la existencia de una opinión pública adversa y en el principio de soberanía continental vinculado a la doctrina Monroe. En consecuencia, la acción exterior orientada por el Estado franquista quedó limitada a un sector cada vez más reducido de las colonias españolas.

Falange difundió en América un nacionalismo español que trataba de suprimir los particularismos regionales y los conflictos de clase mediante la imposición al conjunto de las comunidades de emigrados de un discurso unitarista que las hicieran instrumentos válidos para la acción diplomática diseñada desde España. El Servicio Exterior de FET utilizó durante la guerra civil y la inmediata posguerra un recurso que los fascismos emplearon profusamente en todo momento: monopolizar el discurso nacionalista, desarrollando un fuerte antagonismo frente a las fuerzas políticas y las instituciones prorrepublicanas, y haciendo constantes apelaciones a las masas de emigrantes para que combatiesen activamente a los «malos españoles».

Sin embargo, el hispanismo falangista, que fue derivando del imperialismo totalitario al nacionalismo católico, no fue capaz de actuar como vehículo de conexión y síntesis de los varios sectores ideológicos de las colonias, «nacionalizando» las colectividades de emigrantes mediante la difusión de un proyecto global y coherente de tipo político, ideológico y cultural. Los sectores conservadores más influyentes utilizaron a Falange para recomponer su sistema de dominio tradicional mediante el encuadramiento pasivo de la masa de emigrantes. Por un tiempo, el Servicio Exterior trató de articular un nacionalismo populista y agresivo, que sublimaba la lucha de clases del interior de estas comunidades y no amenazaba los intereses materiales de las élites dominantes ${ }^{128}$. Pero con el comienzo de la guerra mundial, la inteligencia tácita establecida entre Falange y los sectores dominantes de las colonias se rompió, ya que éstos habían establecido de forma permanente su relación económica con las grandes potencias occidentales, y el mantenimiento del apoyo a una organización política de corte fascista y opuesta al imperialismo norteamericano resultaba lesiva para sus intereses.

\footnotetext{
127 IRAZUSTA: Actores y espectadores, pp. 180-181.

128 Delgado GómeZ-EsCALONILla: Imperio de papel, p. 159.
} 
En América, Falange nunca dio el paso decisivo desde un nacionalismo de élites a un nacionalismo de masas, a través de la radicalización y la transformación de un mensaje y simbología tradicionales hacia propuestas modernas, que ofrecieran soluciones a los problemas que pesaban sobre las colectividades de emigrados y las hicieran cobrar un auténtico protagonismo en la vida pública. Sólo postuló la ampliación y mejora de la asistencia social para el trabajador en el extranjero, pero con la intención de transformar a este colectivo en instrumento de una estrategia política con vocación totalitaria y expansionista que fracasó antes de nacer.

\section{EPílogo: LA ESTRATEgIA HISPÁNICA DEL RÉGIMEN DE FranCO ANTE EL ASCENSO DEL PERONISMO}

Este repliegue del discurso hispanista del franquismo hacia el campo religioso y cultural coincidió con la revolución militar que el 4 de junio de 1943 derrocó a Castillo e impuso un gobierno militar opuesto al liberalismo conservador, el fraude y la corrupción del viejo sistema. El poder pasó a manos de unas Fuerzas Armadas en cuyo seno se desarrollaba una influyente camarilla ultranacionalista, corporativista, patriótica y anticomunista: el GOU, que triunfó sobre la corriente residualmente «liberal» del ejército. En un clima de comunión de la cruz con la espada, el régimen patrocinó una «vía militar a la cristiandad» cuajada de liturgias clérigo-militaristas donde la alusión al «mito de la Hispanidad» trataba de proyectar a la «nación católica» argentina hacía los sempiternos valores del «caballero cristiano» — honorabilidad, virilidad y heroismo- exultados años atrás por García Morente. Desde el gobierno se implementaron medidas de claro corte nacionalista: proteccionismo, nacionalizaciones, impulso de la industria manufacturera, o educación controlada por los nacionalistas con el objeto de inculcar en la juventud los ideales católicos, rosistas, medievales e hispanistas ${ }^{129}$.

El nuevo régimen militar fue visto por los nacionalistas republicanos como algo propio, especialmente el programa social propugnado por el coronel Perón, aunque su aparición significó el ocaso del nacionalismo de derecha ${ }^{130}$ y su suplantación por un nacionalismo más dinámico de carácter populista, antiimperialista y democrático ${ }^{131}$, que reconocía la tradición hispánica pero no hacia apología de ella porque ello podía ser confundido como una adhesión sectaria al franco-falangismo.

129 BUCHRUCKeR: Nacionalismo y peronismo, pp. 119-234. Un examen de la ideología católiconacionalista del GOU y de la liturgia religioso-patriótica, en ZANATTA, Loris: Perón y el mito de la nación católica-Iglesia y Ejército en los orígenes del peronismo. 1913-1916, Buenos Aires, Sudamericana, 1999, pp. 26-30, 70-75 y 202-206.

130 NAVARRO GERASSI: Los nacionalistas, p. 194.

131 NAVARRO GERASSI: Los nacionalistas, pp. 138-145 y BUCHRUCKER: Nacionalismo y peronismo, p. 111. 
Muchos nacionalistas (como Gustavo Martínez Zuviría en su cargo de ministro de Justicia e Instrucción Pública, o Mario Amadeo en la Jefatura de la Sección de Asuntos Políticos del Ministerio del Exterior) colaboraron con el nuevo gobierno militar en cargos culturales y diplomáticos ${ }^{132}$. El nacionalismo acabaría por ser fagocitado por el peronismo tras la llegada al poder del general en 1946, transformándose de nuevo en una corriente puramente intelectual.

En septiembre de 1943 llegó el nuevo embajador español, José Muñoz Vargas, conde de Bulnes, con instrucciones de destacar la diferenciación española respecto de los regímenes totalitarios, especialmente su carácter católico y su renuncia a competir con el panamericanismo. Al mes siguiente, el régimen de Franco pasaba de la no beligerancia a la neutralidad. Ese mismo año, los Cursos de Cultura Católica se propusieron crear una cátedra especial para la enseñanza de los valores de la Hispanidad ${ }^{133}$.

Caído Pedro Pablo Ramírez el 9 de marzo de 1944 por el acoso económico y político norteamericano, el nuevo gabinete militar dirigido por Edelmiro Farrell, reconocido por los Estados Unidos en abril de 1945, prohibió todas las organizaciones nacionalistas y se enajenó la influencia de destacadas personalidades de esa tendencia. A partir de ese momento, la corriente nacionalista conservadora o restauradora dejó campo a otra formulación nacionalista en clave populista que sería el origen del peronismo (heredero del nacionalismo popular yrigoyenista, retomado en esos años por FORJA ${ }^{134}$ ), al que se acercaron figuras como Ernesto Palacio o J.M. Rosa. La aparición de un peronismo que asumió muchas de las ideas del nacionalismo supuso el definitivo ocaso de este: los grupos que le habían apoyado se disolvieron y no volvieron a realizar manifestaciones de importancia hasta 1947-48. Muchos hombres procedentes del nacionalismo restaurador (Ignacio B. Anzoátegui, Héctor Llambías, Mario Amadeo, H. Bernardo, Marcelo Sánchez Sorondo) disfrutaron de cargos universitarios y judiciales, pero su acción política no tendió al establecimiento de una fuerza política autónoma, sino a lograr influencia ideológica en los cuadros dirigentes del peronismo y en los sectores mesocráticos de la sociedad argentina ${ }^{135}$.

132 BuCHRUCKER: Nacionalismo y peronismo, p. 281, quien asegura que «la primera etapa de la Revolución de Junio estuvo visiblemente influida por las ideas del nacionalismo restaurador». Sobre las relaciones entre los nacionalistas y el naciente peronismo, vid. también WALTER, Richard J.: «La derecha y los peronistas, 1943-1955», en VV.AA., La derecha argentina. Nacionalistas, neoliberales, militares y clericales, Buenos Aires, Eds. B Argentina, 2001, pp. 249-274, esp. pp. 264-270.

133 ZANATTA: Del Estado liberal a la nación católica, p. 295.

134 FORJA (Fuerza de Orientación Radical de la Joven Argentina), dirigida por Arturo Jauretche, Raúl Scalabrini Ortiz, etc., era un grupo juvenil surgido el 29-VI-1935 para oponerse a los gobiernos militares oligárquicos y al personalismo del líder radical Alvear. Neutralista en la Segunda Guerra Mundial, se disolvió el 15-XII-1945. Su nacionalismo de izquierda propició una cierta convergencia con grupos nacionalistas. Vid. JAURETCHE, Arturo: FORJA y la década infame, Buenos Aires, Ed. Coyoacán, 1962. MuTsuki: Julio Irazusta, pp. 196-199 y Scena, Ángel: FORJA, una aventura argentina (De Yrígoyen a Perón), Buenos Aires, De Belgrano, 1970.

135 BUCHRUCKER: Nacionalismo y peronismo, p. 340. 
A partir de julio de 1945, con el relegamiento de los hispanistas filofalangistas en España (acusados de filofascismo) a partir del nombramiento de Alberto Martín Artajo como ministro de Exteriores, la diplomacia española dejó de considerar al colectivo nacionalista argentino como una base potencial de apoyo al régimen. En contraste con la alta opinión que se tenía de este grupo intelectual en 1941, la actitud oficial pasó de la indiferencia al desprecio ${ }^{136}$. El nuevo objetivo de la atención política española fue el general Perón, cuyo ascenso a la presidencia a mediados de 1946 abrió grandes expectativas de colaboración mutua. Argentina se convirtió en receptor privilegiado de cantidades dedicadas a actividades culturales, dedicadas a difundir la «verdad española» en Latinoamérica. Es cierto que, a partir de 1946, las dictaduras ibéricas eran un residuo del inmediato pasado autoritario de Europa, y que el Vaticano dejaba a un lado posturas integristas para apoyar alternativas democristianas, pero el régimen franquista se dispuso a jugar la baza hispanista menos agresiva, centrada en la sintonía cultural. En 1948 comenzó a actuar una Oficina de Relaciones Culturales vinculada a la Embajada en Buenos Aires, y se intensificaron las misiones culturales y científicas, además de los intercambios de conferenciantes y estudiantes.

Perón adoptó una estrategia cultural que pretendía conjugar el legado hispánico, el catolicismo y la cultura indígenas como elementos centrales en la forja de la conciencia nacional. No resultó sorprendente que, para librarse de los lazos neocoloniales, se remontase al inocuo pasado colonial hispánico. En el discurso del 12 de octubre del 1947, Perón alabó el acervo de España en América y «la historia. La religión y el idioma nos sitúan en el mapa de la cultura occidental y latina, a través de su vertiente hispánica, en la que el heroísmo y la nobleza, el ascetismo y la espiritualidad, alcanzan sus más sublimes proporciones». En otra alocución ante un grupo de intelectuales nacionalistas hispanófilos en noviembre de ese año, el presidente argentino anunció que el gobierno justicialista se proponía orientar la cultura de la nación en un sentido acorde con la raza, lengua y religión españolas ${ }^{137}$. El legado hispánico fue destacado en las escuelas, y se fue identificando con la nacionalidad argentina definida por el peronismo. De este modo los líderes y la prensa peronista elogiarano el acervo español en América sin por ello mencionar especificamente al régimen de Franco.

La Hispanidad se difundió como mito renovado que brindaba un origen común por encima de la diversidad migratoria. Hasta esos años ningún gobierno argentino había adoptado a España y a la Hispanidad como elemento central de su discurso público. Pero ese acercamiento tenía mucho de artificioso, y estaba dictado por la mutua necesidad de mantener opciones diplomáticas alternativas

\footnotetext{
136 GONZÁLez De OlEagA: Las relaciones hispano-argentinas, 1939-1946, p. 209 (El doble juego de la Hispanidad, p. 130).

${ }_{137}$ Cit. por ReIN, Raanan: La salvación de una dictadura, Alianza Franco-Perón, 1946-1955, Madrid, CSIC, 1995, pp. 135 y 138.
} 
frente a la incontestable hegemonía norteamericana en Europa Occidental y América. No tiene, pues, nada de anormal que las percepciones sobre la naturaleza de la vinculación al común proyecto hispánico acusasen una desintonía que podía rastrearse desde inicios de los cuarenta. El análisis discursivo abordado por Marisa González de Oleaga demuestra que no existió coincidencia entre la noción de Hispanidad utilizada por la diplomacia franquista y la contenida en los discursos argentinos de la época ${ }^{138}$. Mientras que la retórica oficial española ordenaba la Hispanidad en torno a rasgos elitistas y jerárquicos derivados de la etapa colonizadora — la recurrente imagen del «caballero cristiano»-, para los gobiernos militares de la Argentina de los años cuarenta la Hispanidad encerraba un componente más popular e incluso indigenista, vinculado a los principios de la soberanía nacional, la justicia social y la libertad, de la que había sido buen exponente los emigrantes llegados a América. España era en discurso argentino (como la Hispanidad lo era en el español ${ }^{139}$ ), un referente o mito histórico que legitimaba un proyecto de futuro: la unidad de América Latina, bajo la hegemonía argentina.

Este idilio filohispanista propiciado por el gobierno peronista coincidió con una campaña cultural dirigida en 1948 sobre la colonia española por la Embajada, en cooperación con el Instituto de Cultura Hispánica. En ella participaron intelectuales como Pedro Laín Entralgo, José María Permán, Antonio Tovar y otros. El viaje del ministro de exteriores Martín Artajo en octubre de ese año marcó el momento culminante de las relaciones, a las que siguió un rápido deterioro con el desmoronamiento de los vínculos económicos y comerciales en 1949, coincidentes con el acercamiento estratégico entre España y los Estados Unidos. La ofensiva antiespañola iniciada por los diarios Crítica y La Época el 6-7 de octubre de 1954 contra la política pronorteamericana de Franco coincidió con la visita a España a Mario Amadeo, abogado católico nacionalista enemigo del peronismo. El gobierno de Buenos Aires mostró su malestar por el trato benevolente que Madrid brindaba a disidentes tan notorios como Amadeo o Goyeneche. Ello agrió aún más las relaciones. Las celebraciones del 12 de octubre de 1954 fueron suspendidas en el último momento por las autoridades argentinas, y a fines de año la ceremonia de la Universidad de Buenos Aires para otorgar el doctorado honoris causa al jurista Francisco Javier Conde fue también suprimida. En paralelo al desbordamiento oficial del sentimiento antiespañol a fines de 1954, atizado por la ofensiva peronista contra la Iglesia Católica, Perón inició un acercamiento a Italia y la latinidad. Pero las presiones norteamericanas, las dificultades económicas fruto de los cálculos erróneos y una coyuntura comercial desfavorable, los roces con la Iglesia, etc. minaron la

138 GonZÁlez DE OleAGA: Las relaciones hispano-argentinas, 1939-1946, pp. 420-422 (El doble juego de la Hispanidad, pp. 256-257).

139 Véase GonZÁlez Calleja, Eduardo y Limón Nevado, Fredes: La Hispanidad como instrumento de combate. Raza en Imperio en la pensa franquista durante la Guerra Civil Española, Madrid, CSIC, 1988. 
estabilidad del régimen, que cayó el 16 de septiembre de 1955 . El nuevo gobierno militar contó con una nutrida cohorte de nacionalistas católicos miembros de honor del Instituto de Cultura Hispánica, como Amadeo en la cartera de Exteriores, Dell'Oro Maini en Educación o Goyeneche como encargado de prensa. En realidad, los nacionalistas habían sido los apoyos más constantes de la España franquista incluso cuando las relaciones comenzaron a deteriorarse a partir de 1949. El gobierno de Madrid invitó a destacados nacionalistas como Gustavo Martínez Zuviría, que fue condecorado con la Orden de Alfonso X el Sanio. También recibieron un trato preferente Manuel Gálvez Matías y su hijo Marcelo Sánchez Sorondo, César E. Pico, Ignacio B. Anzoátegui, Máximo Etchecopar, Carlos Ibarguren, Leopoldo Marechal o Ernesto Palacio, entre otros.

En esos años crepusculares del nacionalismo populista en Argentina, y de apertura violenta del período de dictaduras militares, el franquismo pasó a ocupar definitivamente el puesto de modelo político asumible para un nacionalismo restaurador aterrado con la deriva demagógica y lalicizadora del peronismo. Así se mantuvo hasta el declive y desaparición del dictador, que coincidió con el retorno al poder del peronismo. El «Proceso de Reorganización Nacional» de 1976-83 no tomó como referente identitario dominante la evocación nostálgica del hispanismo, sino que asumió la más agresiva doctrina antisubversiva de la «seguridad nacional» elaborada en los Estados Unidos, junto a una pretendida «defensa de la dignidad del hombre» según los principios de la moral cristiana. Se trataba en realidad de exterminar, o al menos de expulsar de la comunidad nacional, a todo tipo de disidentes, en la más cruda lógica totalitaria. Aún en los años ochenta, cuando el nacionalismo militarista español había desaparecido definitivamente de la escena política tras el fracaso del golpe del 23-F, el nacionalismo argentino mantenía su apuesta reaccionaria por la intervención castrense en las asonadas de los «carapintada» de 1987-88.

El nacionalismo argentino fue un movimiento político surgido en las postrimerías de la década de los veinte en un clima de cambio cultural acelerado, como respuesta primordialmente elitista e intelectual, y no como reacción de amplios sectores de la población ante una determinada crisis estructural en el sistema sociopolítico ${ }^{140}$. En los años treinta, momento en que comenzó a perfilarse la tendencia al intervencionismo militar con el golpe de Uriburu, el nacionalismo se fue afirmando como una corriente entroncada en la tradición

140 Además de las obras ya citadas, otras sobre el nacionalismo argentino: ESTRADA, José María: El legado del nacionalismo, Buenos Aires, Eds. Gure, 1956; SPILIMBERGO, Jorge Eneas: Nacionalismo oligárquico y nacionalismo revolucionario, Buenos Aires, Amerindia, 1958; Troncoso, Oscar: Los nacionalistas Argentinos, Buenos Aires, SAGA, 1957; RAMOS, Jorge Abelardo: Revolución y contrarrevolución en la Argentina (las masas en nuestra historia), $2^{\text {a }}$ ed. Buenos Aires, La Reja, 1961, pp. 333-337 y 387-396; y memorias de nacionalistas: CARulla, Juan E.: Al filo de medio siglo: Hombres, hechos, países e imaginaciones de la Argentina de ayer y de hoy, Paraná, Llanura, 1951; MARTínEZ CASAS, Mario: El país, el dinero, los hombres (relato de una experiencia), Buenos Aires, Theoria, 1957; LEZICA, Manuel de: Recuerdos de un nacionalista, Buenos Aires, Austral, 1968 y GOLDwerT, Marwin: Militarism and Nationalism in Argentina, 1930-1960. An Interpretation, Austin-Londres, University of Texas Press, 1972. 
argentina, a pesar de ciertos rasgos ideológicos recogidos de los movimientos reaccionarios y fascistas europeos. No fue un epígono del fascismo o del franquismo, aunque mantuviera estrechas relaciones con ambos, ni un antecedente necesario del peronismo, sino un movimiento con su propia personalidad y autonomía. Pensaba que la personalidad nacional se fundaba en una vigencia del catolicismo que determinaba los valores morales y su jerarquía en la política. Consideraba que el legado hispánico era uno de los fundamentos esenciales de la nación argentina. Promovió un revisionismo histórico que exaltó la época colonial y el período de gobierno de Rosas y los caudillos federales, y en su rama republicana más radical trató de asegurar la soberanía política a través de la independencia económica y la lucha contra el imperialismo extranjero y el comunismo internacional; peligros causados, según ellos, por el régimen liberal. En realidad, este collage más o menos artificial de fascismo, corporativismo, hispanidad, falangismo y antisemitismo era una forma extrema de reacción conservadora y elitista frente al acceso al poder de la clase media a través del radicalismo, que transformó al país en una democracia con participación popular. En sus mejores tiempos, durante la «década infame», el nacionalismo, en su vertiente conservadora o radical, no logró calar con su ideario antiliberal y ultranacionalista en la oligarquía en el poder, vinculada a intereses neocoloniales y partidaria del mantenimiento de un liberalismo residual, ni consiguió forjarse una base social firme. Resultó evidente que el conservadurismo en el poder durante ese tiempo impidió la creación de un partido nacionalista fuerte, proyecto frustrado también por la inoperancia política de sus intelectuales. El imposible proyecto nacionalista sólo logró alejar durante muchos años a la juventud de una madurez política que podía hallarse fuera de esos brotes de rebeldía de carácter fascistizante, pero la dictadura militar, último recurso de la oligarquía gobernante para prevalecer, se reveló como una solución coyuntural: las clases medias obtuvieron su integración en el sistema a través del peronismo.

A lo largo de ese medio siglo, la capacidad de irradiación de los nacionalismos autoritarios españoles sobre la política argentina resultó muy relativa. Impregnó en muy diversa medida a los intelectuales nacionalistas de cuño católico, que reivindicaron la herencia hispánica como un elemento destacado de la identidad nacional, aunque, como señala acertadamente Zanatta, el hispanismo y sus evocaciones y valores anejos de evangelización, construcción de la cristiandad colonial, primado de los valores militares y respeto de la tradición y de las jerarquías sociales, fueron una atribución a posteriori del catolicismo nacionalista, que permitió una toma de conciencia de la proyección universal de su propia lucha, promoviendo en los años de la guerra mundial una improbable «tercera vía» de naciones católicas neutrales entre las concepciones anticristianas de los totalitarismos y la democracia ${ }^{141}$.

141 ZanATTA: Del Estado liberal a la nación católica, pp. 379-380. Esta misma autora reconoce (p. 291) que «el retorno a los valores de la hispanidad fue para la Iglesia y para los católicos una fase decisiva de la confesionalización del concepto de nación». 
Los nacionalismos españoles actuaron como modelos circunstanciales de algunos regímenes argentinos (sobre todo el primorriverismo en la época de Uriburu), o colaboraron interesadamente con otros (caso del nacionalismo sincrético franquista en la primera etapa de gobierno de Perón). Pero su deriva imperialista explícita y su vinculación, más doctrinal que estratégica, con los regímenes fascistas a inicios de los cuarenta limitaron de forma irreversible su capacidad de influencia en Argentina, salvo en determinados cenáculos intelectuales y en sectores muy concretos de la emigración española. Su proyección exterior fue, en definitiva, tan frustrante como la real influencia del nacionalismo argentino en la vida política del país. 